Portland State University

PDXScholar

$5-1-1970$

\title{
Women in professions and status inconsistency
}

Miriam Grace McClure

Portland State University

Follow this and additional works at: https://pdxscholar.library.pdx.edu/open_access_etds Let us know how access to this document benefits you.

Recommended Citation

McClure, Miriam Grace, "Women in professions and status inconsistency" (1970). Dissertations and Theses. Paper 453.

https://doi.org/10.15760/etd.453

This Thesis is brought to you for free and open access. It has been accepted for inclusion in Dissertations and Theses by an authorized administrator of PDXScholar. Please contact us if we can make this document more accessible: pdxscholar@pdx.edu. 
AN ABSTRACT OE THE THESIS OW Miriam Grace McCiure for the laster of Arts in Sociclogy presented May 20, 1970.

Titie: Women in the Professions and Status Tnconsistenoy.

APFKOVED BY WWMSER OF THE THESTS COMTTYEF:

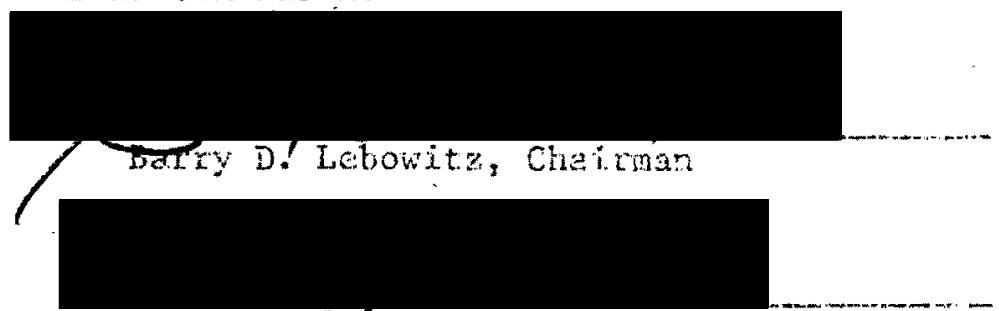

Nona $G, 7 \times]$ Bir

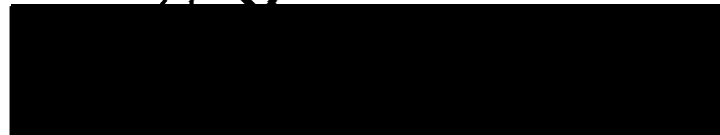

David Cressier

The general concern of this thosis fis with the position of woren In the United States. Speciftcally, the focus ts on vomen in the professions. The theortical perspective is tainen from Everet. $c$. Hughes" 1945 discussion of "Dilemmes and Contradictlone of Status." lughes taintained that wher an incument of a statu holds ar unerpectec auxiliary cheracteristic he is in a dilema because others to not know how to respond to the cortredictory stiwuli. others' resoonses tend to reflect unfavorably beck on the individual's set-irage end he seeks to avofi reasons From others by adopting seluvior to redwee the inpact of the disonepat stritus.

The professions in the lnited states are characterized by a basio body of abstract krowledge and the fieal of service. Tinirteen occupa- 
tione were astatished as professions, ranked on the basis of these characteristies and a boundary line was dxawn between professions and non-professions. A selection of seven profassions was made on wich to test the nypotheses. These seven vere: sedicine, university reaching, dentistry, naturai science, social science, with veterirary mecicine and sccial work marking of the lower boundary.

Wonen in these professions ware consjdered to be in on inconsistent status because they hold the unexpeted characteristin of heing a female status because they hold the unexpected chatacteristie of hesng a fenale In a male doninatad-aewsting and meet the other concitions of status Inconsistency. Since the fericile rrofesstonal can do nothing about changing her Jiscrepant cinaracteristic of being female, it is hypotheslzed that she adopts behavior which Erings har status airaracteristics in arcord and reduces the impaci of her jucousicteul stayts. This behavior may consist of avoidance, isclation andor social segregation on the part of the female professional and her clients or colleagues. The modes of adaptation selected axe the basis of the eight hypotineses of the study: 1) women entar the protessions in smaller proportions than men, 2) women professionals do not participate fully in the colleague-group, 3) women enter positions isolated from the public, 4) women tend to be salaried rather than self-enjugyed, 5) women tend to be in career lines apart from positions of power and prestige, 5) women fill the lower echelons of a profession, 7) wonen specializa in those areas reiating to the nomative'y accepted woman's role, and 8) women tond to deal with patients of equai or lower status.

The data on wich the hypotheses were tested were obtained from many different published sources relating to the seven professions. These sources consfeted in the nat of census tabulations, professional 
dirertories, sumple suveye, National fiducation Association publications, and the Nationa1 legistex of Seientiffe and Techrical Personne1.

It was found that the data genemily supported all the hypotineses with the exception of hypothesis number three which could not be tested. There seems to be a cousiscent pattern for the few women who do enter the professions to enter a limised number of then and to epectalize in those areas which are consistent with the prescribed role of women in Amexican society. Moreover, they tend to teech or.enter researci, work in educational institutious and be on salary. Women are not usually found in the top positions nor the most lucrabive positions within a profession. Further, their carser lines do no: Trad to tile top positions and they tend $t=$ flli the lover echelons within each profession.

It way be concluded that vomen profensionals adopt this pattern throughout the professions, that their career putteril is very different than that of male professionais, and $\mathrm{r}$ is euggested that they adopt this pattern in order to rejuce the impect of their inconsistent status set. 
WOMEN IN PROFESSIONS AND STATUS INCONSISTENCY

\section{by}

MIRIAM GRACE MCCLURE

A thesis submitted in partial fulfillment of the requirements for the degree of

MASTER OE ARTS

in

SOCIOLOGY

Portland State University 1970 
TO THE OFFICE OF GRADUATE STUDIES:

The members of the Committee approve the thesis of Mirlam Grace McClure presented May 25, 1970.

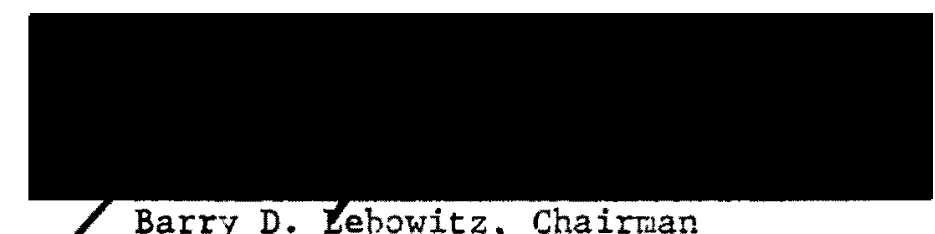

Barry D. Zebowitz, Chairuan
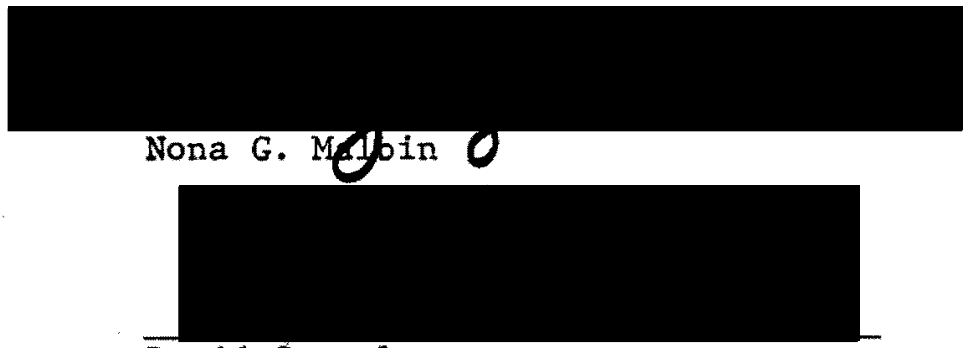

David Cressler

APPROVED:

Charles D. Bolton, Head, Department of Sociology

Frank/ $\bar{L}$. Roberts, Acting Dean of Graduate Studies

May 25,1970 
TABLE OF CONIENTS

PAGE

LIST OF TABLES. . . . . . . . . . . . . . . . . . IV CHAPTER

I INTRODUCTION . . . . . . . . . ...... 1

II STATUS INCONSISTENCY . . . . . . . . . . . 5

Everett C. Hughes' Article . . . . . . . . 5

Analysis of Hughes' Ideas... . . . . . . . . 9

Conditions of Status Inconsistency . . . . . . . . 11

III THE PROFESSIONS. . . . . . . . . . . . . 14

IV WOMEN IN THE PROEESSIONS ............... 23

Women Professionals as Status inconsistents. . . . 23

Behavior to Minimize the Impact of Status

Inconsistency. . . . . . . . . . . . 28

$\checkmark$ HYPOTHESES . . . . . . . . . . . . . . . 31

Behavior ................. 31

VI HYPCTHESES TISTING . . . . . . . . . . . 35

Data................ 35

Hypotheses Concerning Behavior . . . . . . . 37

VII DISCUSSION . . . . . . . . . . . . 81

VIII CORCIUSIONS. . . . . . . . . . . . . . 97 BIBLIOGRAPtiY. . . . . . . . . . . . . . . 104 


\section{LIST OF TABLES}

TABLE

PAGE

I Categorization of Occupations According to Ranking

on the Dimensions of Professionalism. . . . . . . .

II Professional, Technical, Kindred Workers Per Cent

Distribution of Males and Fetules, 1960 . . . . . . 38

III Officers and Administrators of the American College

of Surgeons, by Sex, 1967-68............ 40

IV Officers of the American Association of University

Professors, 1969, and of the American Association

of Junior Colleges, 1970. . . . . . . . . . .

V Officers of the American Dental Association,

by Sex, 1968................... 4 42

VI Officers of Natural Scientific Associations, by Sex . . . 43

VII Officers of the Social Scientific Associations,

by Sex. . . . . . . . . . . . . . . .

VIII Per Cent Distribution of Salaried and Self-Employed

Dentists and Physicians, by Sex, 1960 . . . . . .

IX Per Cent Distribution of Salaried and Self-Employed

Physicians, Dentists and Veterinarians, by Sex, 1960. .

X Medical Specialties, by Median Incomes, Prestige,

Per Cent women and Per Cent Physictans. . . . . . .

XI Private Medical Protitioners, by Field, Per Cent

Women, $1965 . . . . . . . . . . . . . . . .$. 
XII Per Cent Distribution of Income for Physicians,

by Sex, 1959.................... 51

XIII Per Cent Distribution Class of Employment of

Physiclans, by Sex, 1960.............. 51

XIV Type of Practice of Women Physicians, Women as Per Cent

of Total Physicians, Per Cent Distribution of Women

Physicians and All Physiclans : . . . . . . . 52

XV Members of 25 Medical Specialty Boards, 1968. . . . . . . 52

XVI . Faculty of 78 United States Medical Schools, by Rank

and Sex, 1965-66............... 53

XVII Women Professors as Pex Cent of Total Faculty by Type of Institution, Median Income and Rank. . . . . . 54

XVIII Mean Salaries of Faculty, by Academic Rank, Per Cent

Women in 18 Leading Universities. . . . . . . . 55

XIX Median Salaries of College Presidents and Deans, by

Sex, and Per Cent Distribution of Income, by Sex,

1959..................... 55

XX Mean and Median Salaries of Selected Administrative Per-

sonnel in Four-Year and Two-Year Institutions, by

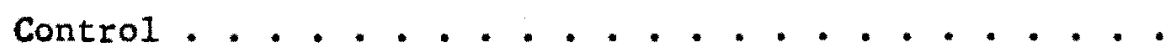

XXI Median Salaries of Professtonal School Positions, 1967-68 . . . . . . . . . . . . . . .

XXII Women as Per Cent of Faculty and Other Professional Staff, 1959 ................... . 58 
XXIII Median Incomes of Dentists by Type of Practice and Per Cent Distribution, 1958. . . . . . . . . 59

XXIV Per Cent Distribution of Median Incomes of Dentists

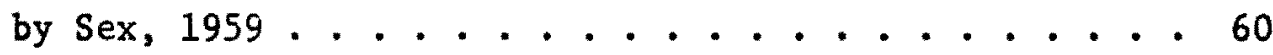

XXV Prestige of Type of Practice and Specialties of

Dentists, 1958 ................. 61

XXVi Type of Employment of Dentists by Sex, 1960........ 61

XXVII Median Annual Salary of All Scientists, Women

Sclentists, by field and Type of Employer, 1966. . . . 63

XXVIII Median Annual Salaries of Scientists, Primary Work

Activity and Type of Employer, 1966. . . . . . . 64

XXIX Median Annual Salary of Scientists by Type of Employer

and Per Cent Distribution, 1966........... 65

XXX Median Salary of Scientists by Primary Work Activity

and Per Cent Distribution, 1966... . . . . . . 65

XXXI Per Cent Distribution of Veterinarians by Income and

Sex, and Median Incomes, 1959. . . . . . . . . 66

XXXII Per Cent Distribution of Veterinarians by Class of

Employment and Sex, 1960............. 66

XXXIII Per Cent Distribution of MSU Veterinary Graduates by

Specialty and Sex, 1939-1965............ 67

XXXIV Social Workers, Excluding Recreation Workers, 1960 . . . 68

XXXV Medical Specialties of Women Physicians, 1965. . . . . . 70

XXXXI Per Cent Physicians in Selected Specialties, by Sex. . . . 71

XXXVII Women as Per Cent of Total Full-Time Teachers, by

Specific Teaching Field, 1954-55.......... 71 
XXXVIII Per Cent Distribution of Women Faculty Members in

20 Leading Universities, by Discipjine, 1960. . . . . 72

XXXIX Per Cent Distribution of Scientists by Field and

Sex, 1966 . . . . . . . . . . . . . . 73

XL Per Cent Distribution of Scientists by Field, Sex and

Type of Fmployer, 1966. . . . . . . . . . . . 74

XLI Per Cent Distribution of Scientists by Field, Sex and

Primary Work Activity, 1966 . . . . . . . . 74

XIII Per Cent Distribution of Women Scientists by Field and

Type of Employer, 1966. . . . . . . . . . . 75

XIIIA Per Cent Distribution of A11 Scientists by Field and

Type of Employer, 1966. . . . . . . . . . . 76

XIIII Per Cent Distribution of Women Scientists by Field

and Primary Work Activity, 1966 . . . . . . . 77

XIIIIA Per Cent Distribution of A11 Scientists by Field and

Primary Work Activity, 1966 . . . . . . . . 78

XIIV Per Cent Distribution of Veterinarians by Type of

Employment and Sex, 1960.............. 79

XIV Per Cent Distribution of Social Workers in Direct Service

Positions, Excluding Recreation, 1960 . . . . . 80

XIVI Per Cent Distribution of Population 18 Years of Age and

Older in the Labor Force by Education and by Sex,

1968...................... . . 102 
CHAPTER I

\section{INTRODUCTION}

\section{Purpose of the Study}

The increasing interest in women's position in the United States as evidenced by the renewed woman's rights movements and in the mass media, necessitates more information and analysis concerning women's position. In accord with this, the purpose in this study is to analyze woman's position as a professional with the focus on her behavicr and the help of those with whon she associates.

The theoreticel perspectlve of this study is taken frodi Everett Cherrington Hughes' discussion in 1945 entilled "Dilemmas and Contradictions of Status." Hughes maintalned that when an incumbent of a status holds an unexpected auxiliary chazecteristic, he or she is in a dilema because others do not know how to zespond to the contradictory stimuli. Others' responses tend to reflect unfavorably back on the individual's self-image so he or she seeks to avoid reactions froa others by adopting behavior to reduce the impact of the discrepant status.

The concept Hughes was concerned with has since come to be known as status inconsistency. 1 It has been a popular concept in the literature

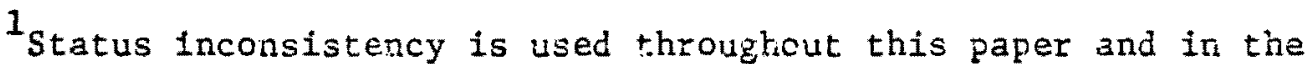
literature to be synoncnous with status incongruence, status discrepancy and to be opfosite from status consistency, status congruence and status crystallization, which are also synonomous and interchangeably used. My focus is on status inconsistency because the subject under consideration, women in the professions, connotes inconsistent statuses. 
and has been examined in relation to soclal participation (Lenski, 1956), symptoms of stress (Jackson, 1962), preference for social change (Goffman, 1957).

For purposes of this paper, the perspective of status inconsistency is taken from Everett Hughes as he applied it to occupations with the goal being to test out some of his Implications on data concerning the particular case of women in the professions.

\section{Plan of the Study}

In order to test Everett Hughes' implications concerning status Inconsistency, we must first understand his perspective. In Chapter II on Status Inconsistency, a discussion and analysis of his article is presented. The dynamic of status inconsistency is discussed. Then the conditions which must be met in order to place an individual in the category of a status inconsistent are considered.

Everett Hughes focused his discussion on occupations; this study deals with the professions. In Chapter III the professions are defined, and a boundary is drawn between professions and non-professions. It is indicated that the professions can be classified according to their ranking on the two dimensions of a) professional knowledge and b) the service ideal. A selection out of the range of the thirteen professions is made of seven professicns in which hypotheses in this study may be tested.

In Chapter IV the particular case of women in the professions is examined. Women professionals may be considered to be status inconsistents since they meet the conditions necessary to be categorized as such. In order to reduce the impact of their inconsistent status, it 
is hypothesized that they and ochers adopt certain behavior. This behavior refers to avoidance, isolation and social segregation. These categorles are then explained.

Specific hypotheses concerning the behavior of women professionals and those with thom they associate are then presented in Chapter $V$. Elght hypotheses are formulated concerning the three categories of avoldance, isolation and social segregation. How each of the hypotheses will be tested is discussed in Chapter VI. Definitions of terms in the hypotheses are given and sources of data are described. Since this study has been done through library research, the data come from a varlety of available publications concerning each of the seven professlons selected.

The hypotheses are tested and the findings presented in Chapter VI. A thorough discussion of the findings is nade in the next chapter with the final conclusions presented in Chapter VIII. 
CHAPTER II

STATUS INCONSISTENCY

Everett C. Hughes' Article

Everett Eughes discussed the dilemmas in which individuals find themselves because of their contradictions of status. He elaborated some of the mechanisms people use in order to reduce the impact of their dilemmas. However, he did not lay out specific ways in which his Ideas could be tested empirically nor did he test them. The purpose of this thesis is to test some of the implications of Hughes' analysis by examining the particular case of women in professional occupations and the effects of status inconsistency on them.

In order to discuss the implications of Hughes' ideas, it is necessary first to summarize his 1945 article. After the summary, I will specify further what I mean by status Inconsistency and how it relates to women in the professions.

Hughes $^{1}$ noted that in our society there are a great variety of social positions and a great number of rank-determining characteristics. In America we put emphasis upon change in social positions and upon social mobility of the individual by achievement. In the struggle for achlevenent, the individual traits of the person tend to stand out as separate entities. And they occur in peculfar combinations which make

$1_{\text {The following discussion and quotations are taken from Everett }}$ C. Hughes, "Dilemmas and Contradictions of Status," American Journa1 of Soctology, 50 (1945), 353-359. 
for confusion, contradiction, and dilemas of status. 2

For any given social status or position, there tends to be specifically determining traits which 1dentify that particular status. These tralts may be formal or legal, e.g., a doctor's license, and require technical competence, e.g., medical. skill. In addition to these determining traits, a complex of auxiliary characteristics develop which come to be expected of the status' incumbents. Roman Catholic priests should be men. Most professionals are men. Certain combinations of these auxiliary characteristics seem more natural and acceptable to people than others. "Thus a white, male, Protestant physician of old American stock and of a family of at least moderate social standing would be acceptable to patients of almost any social category in this country."

These auxiliary characteristics are not necessarily consciousiy put together by people but rather, people carry in their minds these sets of expectations concerning specific positions in our society. These expectations appear as advantageous or disadvantageous to those aspiring to certain positions (new to persons of their kind), depending upon how well or poorly they fit the expectations. These combinations of expected characteristics become embodied in the stereotypes of conversation, cartoons, fiction, motion pictures and television. Hughes asserts it is these stereotypes which are worked most intricately into

2

Hughes takes status to mean "a defined social position for whose incumbents there are cefined rights, limitations of rights and duties." And "since statuses tend to form a hierarchy, the term itself has . . had the additional meaning of rank" (p. 353). 
the sentiment and conduct of the colleague-group or fellow worker group. They become the basis for the colleague-group's definition of its common Interests, of its informal code, and of 1ts selection of those who become the "inner fraternity." The colleague-group has a vested interest in the things which control the number of potential candidates for their occupation. It is a threat to the order of things, which members rely on, if "new" members - new in kind - break or do not abide by the Informal rules of the game of an occupation. The colleague-group is referred to as the "informal brotherhood" In whIch "experiences are exchanged, competence built up and the formal code elaborated and enforced." And new people are not usually drawn into this brotherhood. Hughes maintains that our soclety, in spite of its social mobllIty and heterogeneity, "remains a white, Anglo-Saxon, male, Protestant culture in many respects. These are the expected characteristics for many favored statuses and positions." Prejudice is never directed at these people but rather at people of other races, religions, sex, and ethnicity. Included in the stereotyped prejudices concerning others is usually the assumption that these other people are peculiarly adapted to the places they have held to the present and similarly that they are not quite fit for new positions to which they may aspire. Generally, advancement of the new groups - e.g., women, blacks - to a new level of positions does not eliminate the stereotypes but only modifies them. For example, "in Quebec the idea that French-Canadians were good only for unskilled industrial work was followed by the notion that they were especially good at certain kinds of skilled work but were not fit to repair machines or to supervise the work of others." In this series of modifications the expected qualities for the most-favored positions 
remains intact. At the same time, however, the forces which make for mobilfty continue to create marginal people on new frontiers.

Bughes discusses technical changes which alter occupations and which also create new jobs. These changes work to break up configurations of expected status characterjstics or to lead to a lack of definition in the case of new positions. The new qualifications take time in developing.

But Hughes is more interested in the consequences of the appearance of new kinds of people in established positions. "Every such occurrence produces, in some measure, a status contradiction. It may also create a status dilemma for the individual concerned and for other people who have to deal with him."

The black Anerican in a profession is an outstanding example of this status dilemma. Membership in the black race in the United States may be called a "master status-determining trait." It tends to overpower, in most crucial situations, any other characteristic. But since professional standing is also a powerful charactertstic, these two characteristics clash. The result is a dilemma for those who must deal with the black professional and for the black himself in dealing with others. People must choose between treating him as a black or as a member of his profession. And the black professional must be aware of these discrepant characteristics and determine how he wants to handle them.

One way to reduce this particular status conflict is for the white client to avoid any contact with a black professional. If that cannot be done, then in seeking his help, all non-professional contact must be avoided. Conflict is reduced by keeping the relationship formal and 
specific, e.g., in a doctor's office a specific room is set for the relationship with a door which can be firmly closed when one leaves. Some professions lend themselves to this formal relationship more than others. For example, a family physician and a shoolteacher are more exposed and accessible to the public and may be expected to participate more broadly in the community as compared to a medical or legal specialist who is called in for a specific problem and not expected to enter into any other relationships.

Professional white colleagues may have a particularly difficult time relating to a black professional. The colleague-group is fdeally a brotherhood; to have people in it who cannot be accepted as brothers is very uncomfortable. Further, white professionals may be particularly sensitive to the issue of whom the public - potential and actual clients - sees them meet. To avoid this dilemma, colleagues may often shun contacts with the black professional, particularly if their own reputation is not assured.

The black professional himself has a dilemma. If he appears content with his secondary status within the profession, he may be accused of sacrificing loyalty to his race. Being considered an exception by his white colleagues, he may seek advantage by fostering the idea that he is unlike others of his race.

On occasion there may be cases where the appearance of one or a few individuals of a specific unexpected kind immediately dissolves the old auxillary expectations. But this is not the usual consequence. The expectations usually continue to exist, with modifications and with exceptions allowed. 
A common solution to the dilemna is some elaboration of social segregation. The woman lawyer becomes a lawyer to women clients or she may specialize in some kind of legal service in keeping with women's role such as guardian of the home or of the morals of society. Women physicians may specialize in areas of which only women and children have need. The black male professional may find clients only among blacks. A female electrical engineer is urged to take a job to give the "woman's angle" to design of household electrical appliances. The Negro sociologist generally studies race relations and teaches in a Negro college. Personnel workers who deal only with Negro workers or women workers fit this category, too.

Another solution, which also results in a kind of isolation (if not in segregation), is that of putting the new kind of people in a library or laboratory, where they get the prestige of research people but are out of the view of patients and the public. Such posttions do not ordinarily lead to the positions of corresponding importance in central areas of the occupation. They offer a career line apart from the main streams of promotion to power and prestige.

There are other solutions than these, but the point is that these solutions work to reduce the force of status contradiction by keeping the new kind of person apart from the situations most likely to be troublesome.

\section{Analysis of Hughes' Ideas}

What Everett Hughes seems to be saying, then, has to do with Individuals who do not hold the expected auxilfary characteristics of incumbents of their status, how others respond to this discrepancy, how this response 
In turn affects the individual's self-image and then how the individual adopts certain behavior patterns which minimize the impact of his or her self-image. Hughes discusses the person who holds all the auxiliary characteristics assoclated with his status, the status consistent, e.g., the white, Anglo-Saxon Protestant physician, and implies that others react positively and similarly to him in every situation, according hir. all the prestige and deference due his status. Consequently, the status consistent, in this case, the physician, has a favorable and positive self-image as a holder of that status and has no reason to adopt any behavior to change the reactions of others in order to alter his selfImage.

On the other hand, Hughes points to the person who does not hold the auxiliary characteristics expected of incumbents of his status, the status Inconsistent, e.g., the black physiclan. Here Hughes suggests others are in a dilemma as to how to respond; they may act negatively and/or differently from situation to situation. Others do not accord the status inconsistent all the prestige and deference due one of his status. The status inconsistent has an unfavorable self-image because of the negative or dissimilar reactions of others and seeks to counteract this unfavorable self-image by adopting certain kinds of behavior. To adopt this behavior is rewarding because it serves to maintain his self-image. Hence, not to adopt it is costly in several ways.

Essentially, then, we are dealing with a dynamic process. It is a dynamic process because it shows how the individual's structural position in the social organization affects his self-image. The dynamic link between these two is that of the reactions of others to one's status and associated characteristics. The reactions affect how the individual 
views himslef where positive reactions re-affirm his self-image and negative reactions place his self-image in doubt. In the latter case, the individual will seek to adopt behavior which will avoid the negative reactions of others or make them positive.

Hughes goes on to discuss behavior patterns adopted by status inconsistents which I have labeled: avoidance, 1solation, and social segregation. I will discuss these patterns in detail later.

\section{Conditions of Status Inconsistency}

Certain aspects of status inconsistency must be considered before a researcher may legitimately place individuals in the previouslymentioned category of status inconsistents. First of all, the individual's inconsistent status must be perceived simultaneously by the same people (Malewski, 1966:304). That is, the contradictory stimuli must be perceived by others as contradictory in order for the individual to be in an incongruent status. If the inconsistent stimuli are presented to separate people or groups of people who are not aware of their inconsistency, the individual would not be in an incongruent status. For exampie, an executive who lives in a squalid room is in an incongruent status only if both his co-workers and neighbors are award of the living conditions and occupationa1 leve1, respectively.

Secondly, the Individual himself must be aware of his own inconsistent status. If the individual does not get the message from others that his stimull are discrepant, he will not be aware that they are. If he is not conscious of his inconsistent status, he will not adopt certain behavlor in order to alleviate its impact. It does not follow that from a discrefancy between expected auxiliary characteristics and actual auxiliary 
characteristics one is necessarily aware of this discrepancy. According to Leonard Broom (1959:431), awareness cannot be a priori imputed from measures of status inconsistency. It must be established in each case. Third, the discrepant characteristic or status dimension on which the individual ranks low must be fmportant to the position or status to which the individual aspires. Some characteristics carry more weight than others. The most important Hughes calls "master status-determining traits" because they tend to overpower any other characteristic which are associated with it. I would assume from his discussion that the criteria for being a powerful master status-determining trait would have to do with 1) visibility, whether the characteristic is readily discriminated by others, 2) salience to the society as a whole (such as race in the United States), and 3) the prestige of the occupation associated with the auxiliary characteristics. If a discrepant characteristic ranks high on all these criteria, then it could be considered powerful and come under Hughes' category of master status-determining trait. If a discrepant characteristic is unimportant or not salient to the status, it will. cause less trouble to others and hence to the incumbent. In a discussion of status inconsistency, therefore, it must be established that the discrepant characteristic is relevant to the status.

Similar to the above condition, how different the inconsistent stimuli are also must be considered. Malewski (1966:305) suggests that the greater the divergence between the stimuli, the more uncertain the individual is as to how others will. respond. The tendency is for people to respond to the lower of two status characteristics; therefore the more insecure will become the individual's status. I would suggest that great divergence for Malewskl would mean the extreme case of ranking very high 
on one or more dimensions and ranking very low on another. To give an example, in Hughes' terms, being a white female physician would not be as divergent as being a black female physician. In the latter case the extremes are reached - the stinuli could not be any more divergent. The black female physician would be more of a status inconsistent than the other and would find it more rewarding to eltminate her incongruence, to follow Malewski's analysis.

And finally, these discrepant characteristics nust be shown to be inconsistent with the normative expectations of the environment in which one moves (Malewski, 1966:304). That is, since sftuations vary, each status must be analyzed in terms of the environment to which its incumbent belongs. What may be inconsistent in one environment may be entirely consistent in another. The black physician living and working entirely in a black neighborhood would be fulfilling the normative expectations of a doctor in that environment. He may never encounter nor be aware of any negative reactions to his inconsistent status - inconsistent in a wider context or in another environment.

To categorize individuals as status inconsistents, these kinds of considerations must be made. In Chapter IV, through examining these aspects, it will be established that women in the professions fall into the category of status inconsistents. First, however, we must turn in Chapter III to that special kind of occupation, the profession, in order to establish what we need to know in considering women in such occupations. 
CHAPTER III

THE PROFESSTONS

The professions in America are a category of occupations wich have as their task "the provision of solutions to life's problems that are beyond the capacity of the ordinary, socialized person" (Moore, 1967:319). Professions are characterized by: high income, prestige and influence; high educational requirements; professional autonomy; service to client; licensure; comitment of members to the profession; social sanction; codes of ethics; cohesion of the professional communtty; monopoly ove: task; and intensive adult socialization for recruits. William Goode suggests that a core or generating traits can be abstracted out of such lists of frofessional characteristics. He finds two such central generating qualities: 1) a basic body of abstract knowiedge and 2) the Ideal of service (Goode, 1969:276-80).

Briefly, these two core traits way be described as follows. Professional knowledge refers to an abstract body of knowledge and skills which are ideally codified into a body of principles. The knowiedze and skills should te applicable to the concrete problems of living. It must be accepted by people in a society that the knowledge can solve the problems and that the problems must be given over to a particular group for solution. The profession itself should help to create, organize, and transmit the knowledge of the solutions and should be accepted as the final arbiter in any disputes over its solutions within its area of competence. Finally, a kind of "mystery" should be possessed by the 
profession that is beyond the acquisition of the ordinary man (Goode, $1969: 276-80)$

The service ideal (or the collectivity orientation) is the norm that technical solutions should be based on the client's needs, not on the professional's nor even on society's. It is the professional, however, who decides on the client's needs. The profession demands real sacrifice from the practitioners ideally and in fact, for example, the requirement of prolonged training. People in society seem to believe that the professional accepts, these ideals and actually follows them to some extent. The professional community sets up a system of rewards and punishments such that "virtue pays" (Goode, 1969: 276-80).

Both of these generating characteristics contain many dimensions and each dimension can be considered a continum; with respect to each; a given occupation may fall somewhere toward the professional pole or not. According to Goode, we have no adequate measure for any of these subdimensions and must simply make assertions about where a given type of job may fall. Certain occupations may rank nigh on one dimension and low on others, so that to deternine whether they definitely are or are not full professions becomes a matter of an educated guess. Some occupations are clearly professional because they rank high on all dimensions, e.g., law and medicine. The difficulty arises further down the continuum where the boundary between professions and non-professions blurs $\mathscr{C}$ Nursing, librarianship and teaching would rank relatively high on the service Ideal but low on the professiona]. knowledge dimension. Etzioni calls these semi-professions (Etzioni, 1969:v-vi) and Goode claims they never will be professions because their bureaucratic framework prevents It (Goode, 1969:280-81). Barber (1967:23), however, considers the elite 
of these and other marginal professions to be professlonals; such is not the case with the rank and file in the occupation.

Even if we could accurately rank and measure precisely where each occupation 1isted in the United States Census Classifled Index of Occupaand Industries falls on each of the dimensions and subdimensions of professionalism, there would still be this probiem of the dividing line. Where and on what basis is it drawn?

For purposes of our study, it is cruclal that we do differentiate between the professions and non-professions. Crucial because many of these semi- or marginal professions are female-dominated occupations. And if data based on predominately female occupations are used to test the hypotheses, as against predominately male occupations, very different kinds of results may be obtained from one or the other.

One way to get around this issue (without really deciding it) is to see what occupations have been classifled as professions by sociologists. The first to discuss professions and categorize them was Alexander Carr-Saunders (in Toren, 1969:141-94) in the 1930's. He divided professions up into four major types: 1) the established professions: 1aw, medicine and the church; 2) the new professions which are based on their own fundamental studies: engineering, chemistry, accounting and the natural and social sciences; 3) semi-professions based on acquisition of technical skill: nursing, pharmacy, optometry and social work; and 4) the would-be professions based on neither theoratical study nor technical skill but rather a familiarity with modern practices in business, adrinistration and current conventions, such as, hoepital managers, sales managers, work managers, etc. 
William Goode (1969:280-81) describes the four great traditional professions - the person professions: law, medicine, university teaching and the clergy. Architecture is marginal to these four. The new professions which have become professions in the last generation are: dentistry, certified public accounting, clinical psychology and certain high levels of the scientific and engineering fields, such as electronic engineering, cryogenics, aercnautical engineering and so on. The followIng he predicts will achieve professional status over the next generation: social work, marital counseling and perhaps city planning. Finally, he includes a list of occupations that he predicts will not become professions: none of the medical branches except possibly veterinary medicine, nor nursing, osteopathy, chiropractice, pharmacy, schoo1-teaching, 11brarianship, business management, public relations and advertising.

Finally, Harold Wilensky (1964:141-42) lists the established professions as law, the clergy, university teaching, military, dentistry, architecture, some areas of engineering, certified public accounting, scientific and engineering fields. Those occupations still in process of becoming professions, according to him, are: social work, correctional work, veterinary medicine, city planning and "executives." His borderline cases are school-teaching, librarlanship, nursing, pharmacy and optometry.

From these lists we can observe agreement on certain occupations as professions: medicine, law, university teaching, the clergy, dentistry, architecture, accounting, scientific and engineering fields. City planning, veterinary medicine and social work are considered to be in process by Wilensky, but predicted to achieve professional status by 
Goode. Although Carr-Saunders includes social work in the semi-professions, because of the early date of his study, more weight may be given to the later writers. Social work has changed considerably in the last 40 years, and may indeed now be a profession.

Clinical psychology was specifically mentioned only by Goode as being a new profession, but Carr-Saunders Included the natural and social sciences in general. From his discussion, Wilensky seems to group the social sciences with the "scientific and engineering fields." Marital counseling was only mentioned by Goode as achieving professional status In the future while correctional work and "executives" were the only ones mentioned by Wilensky as being in process. Hence, these occupations will be omitted from the study for lack of consensus about their status as professions. Nursing, pharwacy, Iibrarianship, school-teaching, and optometry are described as semi-professions (Carr-Saunders), not becoming professions (Goode), and borderline (Wilensky). Consequently, they too will be excluded from consideration as professions. The only other field mentioned was the military. This occupation will of necessity be excluded from consideration because of its discrepant rules of entrance, e.g., men are drafted, women volunteer, and jobs in the military are sex-1inked by formal regulation, i.e., women are excluded from front-line combat. For this study, then, we will. look at the following established professions: medicine, law, the clergy, unfversity teaching, dentistry, architecture, certified public accounting, social sciences, natural sclences, and engineering. The three occupations agreed to be "in process" will mark off a lower diviaing line, $1 . \epsilon .$, veterinary medicine, social work, and city planning. Thus, thirteen broad professions are avallable from which to select professions on which hypotheses can be 
tested. It should be noted that these thirteen can overlap, i.e., a university teacher could also be a lawyer, doctor, engineer, social scientist, etc. Differentiation will thus be made purely on the basis of the specific data available.

Now that these thirteen are decided upon, we may look again at the two core generating traits described by Goode $(1969: 276-80)$. If it is possible to rank these thirteen professions on these two core traits, then we could select a smaller number of professions over the range of professionalization on which to test the hypotheses.

With regard to the professional knowledge trait, professions could be judged on the abstraction of the body of knowledge, whether it is codified into a body of princlples, its applicability to concrete problems of living, the relegation of the problems for solution to a particular group, the professional judgement of competence, and the professional responsibility for organizing and transmitting that knowledge. On the service ideal trait, professions would be ranked according to whether their solutions are based on the client's needs, if the client's needs are determined by the practitioners, if the practitioners undergo some sacrifice, e.g., extensive training, and if the rewards and punishments are in line with the service ideal rather than sowe other, e.g., the business ideal.

One caution should be noted. In comparing the scientists' profession with that of other professions, designation of the client becomes a problem. Wilensky (1964:141), however, equates the scientist's disinterested search for truth with the professional's technical service Ideal and further, "where a sctentific discipline has a substantial segment of its adherents fully engaged in applied work, the requisites of a profes- 
sion are generally met."

In ranking the 13 professions on the two core dimensions, we can place medicine, law, the clergy and university teaching toward the most professional end, because these four tend to rank high on both the professional knowledge dimerision and the service ideal dimension. They have an advanced body of abstract knowledge which is codified into a body of principles which are applicable to problems of clients. They have a socially approved area allocated to them, are their own final judges, and are held responsible for transmitting their knowledge, e.g., medical, law, theological schools and graduate schools in the different disciplines for university professors exist to carry out the transmission function.

After these top four would come architecture, dentistry, certifled public accounting and engineering. This group of occupations ranks lower on the knowledge dimension than the top four because their body of knowledge is not as abstract but is more technical. They may not be as tightly controlled by those inside the profession but must accede to authority of laymen in some cases (engineering). On the service ideal dimension, this group of occupations ranks relatively high because they are providing a service to the cllent based on his needs as they are determined by the practitioners.

The next lower group are the sclentists, natural and social, who would rank high on the knowledge dimension. Their knowledge is very abstract. Depending on the discipline, it is generally accepted that their knowledge can solve problems, if not immediate problems, then longrange. They are thelr own final judges and are organized to transmit their knowledge. The scientists' disinterested search for truth initially 
places them high on the service ideal but the lack of extensive applied work ultimately reduces their position on the service ideal.

The last three occupations, veterinary medicine, social work, and city planning, fall below the rest on the continuum of professionalism for several reasons. Veterinary medicine would rank low on professional knowledge because people in society are not willing to grant them autonomy and professional status on the basis of treating animals. The stakes are not high enough (Goode, 1969:296). Socjal work ranks high on the service ideal but because their professional knowledge lacks definition and high abstraction, because they are not autonotous but work within a bureaucratic framework and are judged by non-professionals, they rank at the low end of professionalism. City planning is at the low end also because their body of knowledge also lacks definition and codification. They are given by the public neither the authority to deal with their area of problems nor the approval that they are best able to solve those problems, compared to governmental agencies and bureaus. They are judged by non-professionals, usually politicians and taxpayers. They do not have a.clear-cut, professionally agreed-upon educational program, i.e., people from a variety of backgrounds may become city planners. Cicy planners rank slightly higher on the service ideal, however, in that they are generally collectivity-oriented and decide on solutions based on needs of their client, 1.e., what is best for the city. This overall ranking is illustrated in Table I. 
TABLE I

CATEGORIZATION OF OCCUPATIONS ACCORDING TO RANKING

ON THE DIMENSIONS OF YROFESSIONALISM

\begin{tabular}{|c|c|c|c|c|c|}
\hline \multirow[t]{2}{*}{ " } & & \multicolumn{4}{|c|}{ Professional Knowledge Dimension } \\
\hline & & $\mathrm{HI}$ & & LO & \\
\hline $\begin{array}{l}\text { Service } \\
\text { Ideal }\end{array}$ & $\mathrm{HI}$ & $\begin{array}{l}\text { medicine } \\
\text { law } \\
\text { the clergy } \\
\text { university } \\
\text { teaching }\end{array}$ & B & $\begin{array}{l}\text { dentistry } \\
\text { architecture } \\
\text { certified } \\
\text { public } \\
\text { accounting } \\
\text { engineering }\end{array}$ & $\begin{array}{l}\text { [veterinary } \\
\text { medicine] } \\
\text { [social work] } \\
\text { [city planning] }\end{array}$ \\
\hline Dimension & LO & $\begin{array}{l}\text { natural C } \\
\text { sciences } \\
\text { social } \\
\text { sciences }\end{array}$ & $\mathrm{D}$ & non-professions & \\
\hline
\end{tabular}

Veterinary medicine, social work and city planning would fall in Category $B$ as all three ara slightly higher on the service ideal than the knowledge dimension. But they are still in process of becoming professions and hence mark off the boundary of professions.

To simplify the study, reduce the amount of data and allow greater depth, a selection out of this list of professional occupations will be made. For contrast, I am selecting two traditional professions, two professions on the border, and three in between: medicine, university teaching, dentistry, natural sclence, social science, social work and veterinary medicine. Data on these seven professions will be analyzed in terms of the inconsistent status of women within their ranks. 


\section{CHAPTER IV}

\section{WOMEN IN THE PROFESSIONS}

\section{Women Professionals as Status* Inconsistents}

Applying Hughes' ideas and the analysis of them to women in the professions, we find that women professionals do not hold the expected auxiliary characteristics of professionals. According to Hughes (1945: 354-55), the auxiliary characteristics associated with professions in America have to do with being white, male, Protestant, Anglo-Saxon and of a famlly of at least moderate social standing. This combination is prevalent in the nass media and everyday conversation. It is particularly prevalent in professlonal colleagues' images of themselves and of other colleagues.

The woman professional ranks low on the dimension of sex, that is, being female rather than male. She presents discrepant stimuli to others, her colleagues and the public; they do not know whether to respond to her as a woman or as a professional. If others respond to her as a professional and ignore her femaleness, this supports her self-image of being a professional and she finds this favorable. However, if Malewski's assertion is correct that people usually respond to the lower status characteristic, she will more often be faced with the situation where others respond to her fenaleness, jgnore her professional standing, and refuse her the prestige due her status as a professional. Since she views hersel $\vec{I}$ as a professional, her self-image will be impaired when she 
is treated as a female. She is caught in a dilema which may be repeated in every situation unless she is able to prevent it. Since it Is impossible to raise the lower of the two discrepant characteristics, i.e., changing from female to male, she may seek to reduce somewhat the higher of the two characteristics, that of professional standing. In this way she would be bringing tine two characteristics more in accord with each other - lowering the higher characteristics to be in Iine with the unchangeable lower characteristic. G. H. Fenchel et al. (1951) noted this tendency to coordinate status characteristics in his concept of the equilibration hypothesis. Whether it is best sonceptualized as an equilibrium tendency or not, the status incorsistent dues seek to minimize the impact of his inconsistent status by adopting ceztain kinds of behavior. In the case of the woman professional, this behavior may refer to not aspiring to full professional standing and filling peripherai needs of the profession (which reduces her higher status characteristic or other behavior patterns of avoidance, isolation and social segregation (wtich serve to manage or avold situations which bring reactions from other:s).

It should be pointed out that we are dealing with the womar professlonal in her proressional role. This is where she is faced with this dilemma of presenting two incongruent stimuli. In her other roles - as wife, mother, consumer, etc. - she is not in an inconsistent status because she is performing what is normatively expected for the female role, particularly as long as she Joes rot mention that she is a professional. But in her professional role, she comes into contact with people who hold different expectations for professional people than that of being a woman. Her colleagues and the public oust decide which stinuli 
to react to when faced with the situation. And she must decide how to cope with a variety of responses.

We have established so far that the female professional is in an Inconsistent status just by being a woman in a male-dominated occupational structure. To categorize legitimately a woman professional as a status inconsistent, however, some further considerations must be made. First, perception of the Inconsistent stimuli by others wust occur simultaneously. "Others" in this case comprise two groups: her male colleagues and the public. Due to the visibility of being female and being in a professional role with male co-workers, her colleagues cannot be unaware of her discrepant characteristics. They immediately and simultaneously perceive her contradictory stimulf. And colleagues are even more susceptible to this conflict than the publfc, because colleagues have their own public image to uphold. Their own self-images are thus involved because of possible reactions by the public to their aliowing those of infericr status to enter their profession. The publia with whom she comes into contact in her professional role are usually clients or patients. Because of her visibility as a female and her performance in a professional role, the public also cannot avoid being aware of the discrepancy in these two characteristics with respect to a male-dominated profession.

The second consideration which must be made has to do with the socialpsychological question of awareness. We have sald the woman professional Is In an inconsistent status by being a woman in a male-dominated occupation. This is percelved by others with whom she associates. Their reactions to her femaleness while she is adhering to professionalism makes her aware of this inconsistency. This awareness is reinforced by other things. 
The professional world is usually a man's world where the daily routine and accomodations are geared for men and not for women. The woman professional is continually faced with this reminder that she holds an unexpected characteristic in the role. Further, images of the preferred woman's role in the mass media and from friends, husbands, and relatives continually remind her that she is engaging in a role not normatively expected of her. This is aggravated if there are children involved as In most cases their dally needs are expected to be her responsibility. So st is a fair assumption that she is aware of her incongruency. The third consideration has to do with the importance or sallence of the discrepant characteristics. Sex and professional standing are both master status-determining traits, to use Hughes' terminology, because they rate high on the three criterfa of 1) vistbility: there - could hardly be a more visible characteristic than being a woman and as for professional standing, a professtonal usually makes his standing known quite readily to be able to cash in on the prestige due him; 2) salience: woman's role - "motherhood and apple pie" - are dear to the hearts of most Americans and the professions play such a vital role in solving people's problems that people are generally pretty concerned about who professionals are and how they act; and 3) prestige: the professions as a group have the highest rank on the prestige scale in the United States (Hodge, et a1., 1966:324-25).

The fourth consideration has to do with Malewski's concern with divergence of the contradictory stimuli. If "divergence" means "extremes," professional standing ranks highest on the scale of occupations in the United States, while of the two sexes on the scale of se\%, female ranks lower. If a11 other status aimension rankings are assumed equal, these 
two rankings are thus found to be at opposite poles. Consequently, the woman professional is probably more uncertain as to how others will respond and her status is more insecure than would be the case if rankIngs of these traits were closer together.

Finally, the environment in which the woman professional moves has already been shown to be one in which the inconsistent status of the woman professional is readily apparent. Performing as a professional while exhibiting her femaleness is an acute reality both for her pubiic and her colleagues. Both the public (clients, patients) and her colleagues expect her to be a "him." This is true in most instances. There may be some professional levels within the professton for which sex is not relevant, e.g., assistants, researchers. But generally the normative expectations for each environment should be raised for each profession, however, because the professions vary so greatly from each other.

To sumarize, women in professions are in a dilemma because they present two contradictory stimuli, that of being female and that of holdIng professional standing. Accordingly, others do not know how to respond to her, and more often than not will respond to her femaleness first. This may be damaging to her self-image as a professional; she may have to take steps to maintain her self-image and prevent situations in which this will recur. We have established that the woman professional is a status inconsistent because: others perceive her contradictory stimuli, she is aware of her inconsistent status, there is a strong normative expectation for maleness associated with professional standing, she holds the lowest ranking on the auxiliary characteristic of sex, and in most cases, the environment in which she moves has the normative expectation 
of maleness for professionals.

Behavior to Minimize the Impact of Status Inconsistency

The female professional seeks to maintain her self-image as a professional. To do this she adopts behavior which minfmizes the impact of her being a woman in a profession. Hughes discussed many kinds of behavfor which may be categorized under the following three categories:

1) AVOIDANCE. The public can refuse to patronize a female professional. If this cannot be done, the layman can avold any non-professionai contact with the female professional. The relationship may involve only the amount of time it takes for the professional to extend her services to the client. It may involve highly formal conversation concerning only the specific service being performed. It may involve a set place soleiy designed for the rendering of the service and no other. The place may also be private and out of view of the public.

Her male colleagues may also act like the client towerd the female professional. That is, they may keep their reiationship formal and specific, and avoid any non-professional cortact with the femele professional. They may particularly avoid associating with the female professional in public or where potential or actual cllents may see them and judge them.

The female professional uses the avoldance principle also. Where there is a chance for difficult situations to arise with colleagues or the public because of her discrepant status, she may seek to avoid contact with them a1so. She may also work to keep the relationship formal and specific and avold any non-professional contact. This may be difficult for her to accept as a professional and she may try to act 
like "one of the boys" most of the time, avoiding instances where it is Impossible. She may foster the idea that she is really a pal and unlike most other women. She may be jealous of her own status, which may be second-class, and seek to exclude other female professionals from the profession in order to assure her status.

2) ISOLATION. This principle is related to. the first and refers to instances where the female professional is isolated from situations which may be difficult because of her inconsistent status. The fenale professional may choose or is allowed entrance into the profession only in areas which are out of the way of patients or the public. Thus, female professionals are often found in the libraries or laboratories away from and invisible to the public or patients. They are given the prestige of research people but are out of the way. They are "kept apart from the main streams of promotion to power and prestige," accordIng to Hughes. They have the advantage of feeling they are professional, a part of the profession, but in this way, they do not harm the power structure of the inner fraternity. The male colleagie-group still retalns control by allowing the female professional in part way and only In areas which are outside of the power lines.

3) SOCIAL SEGREGATION. The third principle inferred from Hughes' article has to do with segregating the female professional. That is, the female professional is allowed into the professton only in certain areas within the profession and/or into areas which are in keeping with her role as a woman. Conversely, she try choose to enter certain areas which tend to minimize her Inconsistent status because they are more in keeplng with her rols as a woman. In other words, she is socially segregated into certain acceptable areas and prevented from freely participa- 
ting in other areas of her profession, or she segregates herself in this way. For example, the woman lawyer becomes a lawyer only to vomen clients. The woman physician is usually found in pediatrics treating children, or in gynecology treating fenale disorders. Or a female personnel manager may be hired to deal with women amployees.

Essentially, then, when discussing these three categories of behavlor, the focus is on two main relationships: the professional-colleague relationship and the professional-public relationship. Avoidance of the professional by the fublic, and of the public by the professional. Avoidance of the professional by her colleagues and of her colleagues by the professional. Isolation of the professional by her colleagues and 1solation by herself. Social segregation of the professional by the public, by herself and by her colleagues. Each behavior pattern operates slightly differently but the goal of all of them remains the same, i.e., reducing the impact of status inconsistency. These patterns of behavior will now be further detailed and converted into hypotheses. 


\section{CHAPTER V}

\section{HYPOTHESES}

\section{Behavior}

The kinds of hypotheses of concern here have to do with behavior, the behavior that women in professions and those with whom they associate adopt in order to reduce the impact of the inconsistent status characteristics.

It should be noted that the behavior taken to reduce the impact of status inconsistency on the part of the status inconsistent may be closely related to behavior taken on the part of those with whom he associates. In some cases these are two sjdes of the same coin; in other cases, they may not be related. What I am referring. to, e.g., in the case of women professionals, is the case where the only opening into the profession for the woman is a position in the library. To say that she chooses the position in the library to avoid contact with the public in order to reduce the effect of status inconsistency would be misleading. It is the only alternative open to her so she has no choice. She may not be trying to minimize her inconsistent status but just trying to get into the profession. On the other hand, it may be those in the profession who are trying to minimize her status inconsistency by reducing her contact with colleagues and the public. It is difficult to differentiate between behavicr adopted by the status inconsistent herself and behavior adopted by those around her when the result is the same, i.e., that of reducing 
the impact of status inconsistency.

An example of a case of unrelatedness would be that women professionals tend to marry other professionals and many times ones in the same field (Stafford, 1967:317; Ginzberg, 1968:6). She may reduce her inconsistent status by marrying a colleague and close the gap between her role as wife and that of professional. This is behavior taken for the most part on her own, unrelated to and out of control of those in her profession, with the exception of the broader issue of social class.

So for each hypothesis, attention will have to be given to this difficulty of differentiating just whose behavior we are talking about. It should be remembered, though, that many times it is two sides of the same coin.

Hughes discussed the kinds of behavior adopted to reduce the impact of status irconsistency which I have subsumed under three categories of behavior. Hypotheses will be derived from these patterns of behavior. Implicit in every hypothesis, it must be remembered, is the assumption of ceteris paribus, all things being equal.

1) AVOIDANCE. This principle refers to avoiding the effects of status inconsistency of a female professional. On the very basic level, the best way for a woman to avoid the status inconsistency of being a professional in a man's world and for those in the profession to avoid the impact of status inconsistency of a colleague is for the woman not to enter the profession in the first place and for the professionals to prevent women from entering the profession. Consequently, one wouid expect to find small percentages of women in the professions as compared to men. 

$\mathrm{H}_{1}$ : Women tend to be in the professions in smaller propor-
tions than men.

On the next level, avoidance refers tc avoiding contact with the female professional by the pubiic and her colleagues, and if not possible, keeping the professional relationship formal and specific. The public, her colleagues and the female professional all strive to avoid situations where there is a chance of a reaction to her inconsistent status. Non-professional contact is avoided.

$\mathrm{H}_{2}$ : Women in the professions do not participate fully in their colleague-group.

2) ISOLATION. This principle refers to the female professional entering activities and being encouraged and/or allowed into activities which are isolated from situations which may be difficult because of her incongruent status. These activities refer to working in libraries or research laboratories apart from the view of patients/clients and the public.

$\mathrm{H}_{3}$ : Women in the professions tend to be in positions isolated from the public and patients/clients.

Since these kinds of positions tend to be in institutions as against private practice, and also for other reasons, we might expect to find more professional women on salary than in private practice. Other reasons include closeness to women's role of being subordinate rather than independent or assertive as in private practice. $\mathrm{B}_{4}$ : Women in the professions tend to be salaried rather
than be self-employed.

According to Hughes, women in the professions are kept apart frota the mainstreams of promotion to power and prestige. That is, they are allowed into the profession only part way and where the control of the profession by the inner fraternity is not threatened. In the sane manner, women in the professions choose to enter areas which are apart from power 
and prestige in order not to threaten the power structure and thereby Jeopardize her position.
$\mathrm{H}_{5}$ : Women in the professions tend to be in career lines apart from the mainstreams of promotion to power and prestige.

Related to hypothesis number five would be an examination of women in the same career lines as men. In this case they would still tend to be kept apart from the power structure - the elite levels in the profession.

$\mathrm{H}_{6}$ : If in the same career lines as men, women tend to men advance.

3) SOCIAL SEGREGATION. The third principle has to do with the woman professional speciallzing in certain areas relating to her female role and those in the profession segregating her into certain approved areas away from the rest of the profession.

$\mathrm{H}_{7}:$ Women in the professions tend to specialize in those
areas relating to the normatively accepted women's role.

$\mathrm{H}_{8}$ : Women in the professions which have clients or patients tend to deal with clients or patients of equal or lower status. 
CHAPTER VI

HYPOTHESES TESTING

\section{$\underline{\text { Data }}$}

The eight hypotheses corcerning behavior of women professionals and of those with whom they associate w111 be tested on data from each of the seven professions discussed in Chapter III. The data are taken from a variety of sources through library research. There is very Iittle information on the professions by sex, income, specific positions and avenues of promotion. It seems it is not of particular interest to each profession to focus on the women within its ranks. Consequently, the data used in this study can at best reflect tendencies within the professions.

Because the data were taken from many sources, they vary in accuracy In reflecting the entire profession and in consistency in comparing one variable from one source of data with another variable measured on another source. For example, statistics on the medical profession in Medical Economics include only private practitioners; they are not broken down by sex. The study on physicians in public health by kosa and Coker (1965) focuses on only a sample of those who had at one point worked for public health. The Census descrtbes only broad categories of "physicians and surgeons," "salaried" or "self-employed" but does break them down by sex. Statistics on women in the professions by the women's medical organization - the American Medical Women's Assoclation - show the distribution of all women physicians, type of practice, etc. (based 
on figures from the AMA), but do not have ccuparable figures for men. From this picture, the difficulty of contrasting these diverse kinds of data is demonstrated. For each profession, there are similar difficulties to a lesser or greater degree.

However, the diversity of the data is also an asset. If by piecIng together data from many sources and ending up with a fairly consistent picture of women's position within all these professions, the conclusions may be given more weight. The possibilities of ending up with many diverse conclusions is great using this method so if they all point to the same tendency, indeed there must be something there. A good possibility also exists that other investigators looking at similar kinds of questions will come up with the same picture.

Data were obtained from the following sources: the United States Census of the Population; the directories of the professions put out by the professional associations, including rosters of their officials; National Education Association publications concerning salaries in higher education; Women's Bureau publications, in particular the Handbook on Women Workers for different years; studies in journals and books on the position of women within specific professions and on the professions; Amertcan Science Manpower, which is a sumary of the statistics gathered In the National Register of Scientific and Technical Personnel.

Data were gathered on the seven professions: medicine, university teaching, dentistry, natural and social sciences, veterinary medicine, and social work. The data are presented in the form of tables with the specific source listed below the table. In some cases, comparable data were not avallable so data on different years were presented simply for contrast, not as an accurate statistical representation for any one year. 


\section{Eypotheses Concerning Behavior}

A description of how each of the elght hypotheses was tested and a presentation of the findings in the form of tables and comments follows. In the next chapter a thorough discussion of the results will be glven.

$H_{1}$ : Women tend to be in the professions in smalier proportions than men.

Census data concerning detailed occupations, by sex, is presented in Table II. Since census data tend to show a general overview of the professional picture (professionals are categorized with technical and kindred workers and everyone vaguely related to a profession could fall Into that category), other data alay be helpful.

The 1969 Handbook on Women Workers (Women's Bureau, 1969) shows that women represented:

$7 \%$ of the physicians in 1968

$18 \%$ of the faculty in colleges and universities in 1965-66

$22 \%$ of the faculty and other professional staff in colleges and universities in 1965-66

$8 \%$ of the scientists in 1966 listed in the National Sclentists Register (includes social and natural scientists)

The 1962 Handbook on Women Workers 1 ists women as $59 \%$ of all social we1fare workers.

The Office of Education report of degrees conferred in the United States 1ists 3.8 per cent of all graduates receiving Doctor of Veterinary Medicine degrees as women In 1963-64 (Giuliani and Centra, 1968). $\mathrm{H}_{2}:$ Women in the professions do not particlpate fully in
their colleague-group.

If women participated fully in their colleague-group, one would expect to find their names on the membership roster and list of officials of the professional organizations associated with the professions in the 
TABLE II

PROFESSIONAL, TECHNICAL, KINDRED WORKERS

PER CENT DISTRIBUTION OF

MALES AND FEMALES

1960

\begin{tabular}{|c|c|c|c|}
\hline Occupation & Total & $\begin{array}{l}\text { Male } \\
\% \text { Total }\end{array}$ & $\begin{array}{l}\text { Female } \\
\% \text { Total }\end{array}$ \\
\hline $\begin{array}{l}\text { College Presidents, Professors, } \\
\text { Instructors (nec) }\end{array}$ & 178,676 & 78.0 & 21.9 \\
\hline Dentists & 83,198 & $97: 7$ & 2.3 \\
\hline $\begin{array}{l}\text { Natural Scientists } \\
\text { Agricultural Scientists } \\
\text { Blological Scientists } \\
\text { Chemists } \\
\text { Geologists and Geographers } \\
\text { Mathematicians } \\
\text { Physicists } \\
\text { Misc. Natural Sclentists }\end{array}$ & $\begin{array}{r}151,130 \\
7,987 \\
14,057 \\
84,349 \\
18,931 \\
7,685 \\
14,014 \\
4,107\end{array}$ & $\begin{array}{l}90.0 \\
94.8 \\
73.1 \\
91.2 \\
97.7 \\
73.4 \\
95.7 \\
90.3\end{array}$ & $\begin{array}{r}10.0 \\
5.2 \\
26.9 \\
8.8 \\
2.3 \\
26.6 \\
4.3 \\
9.7\end{array}$ \\
\hline Physictans and Surgeons & 229,590 & 93.2 & 6.8 \\
\hline $\begin{array}{l}\text { Social and Welfare Workers, } \\
\text { excluding Group }\end{array}$ & 97,911 & 37.2 & 62.8 \\
\hline $\begin{array}{l}\text { Soclal Sclentists } \\
\text { Economists } \\
\text { Psychologists } \\
\text { Statisticlans and Actuartes } \\
\text { Misc. Social Scientists }\end{array}$ & $\begin{array}{r}57,155 \\
19,348 \\
12,126 \\
22,134 \\
3,547\end{array}$ & $\begin{array}{l}74.8 \\
85.4 \\
68.8 \\
69.3 \\
72.9\end{array}$ & $\begin{array}{l}25.2 \\
14.6 \\
31.2 \\
30.7 \\
27.1\end{array}$ \\
\hline Veterlanarians & 14,906 & 97.9 & 2.1 \\
\hline $\begin{array}{l}\text { Total "Female" professions: } \\
\text { nurses, teachers, librartans, } \\
\text { dietitians, social workers }\end{array}$ & $2,332,371$ & 20.8 & 79.2 \\
\hline $\begin{array}{l}\text { TOTAL: a11 professional, tech- } \\
\text { nical and kfndred workers }\end{array}$ & $7,335,699$ & 61.9 & 38.1 \\
\hline
\end{tabular}

nec $=$ not elsewhere classified. U. S. Bureau of the Census, Subject Reports.

Source: Unitted States Census of Population, 1960, Occupational Characteristics, PC (2) -7A (Washington, D. U.: U.S. GPO, 1963), Table 201, p. 1-923. 
same proportions as women occur in the profession. However, the main professional organizations are difficult to determine (particularly in the sciences and university teaching); statistical information by sex is not included in the directories of the professional associations nor elsewhere; the prevalence of the use of initials prevents independent counting the number of women In the directory. For these reasons, this hypothesis will have to be tested another way.

Listing of officers is included in some dizectories and fournal publications so the percentage of female officers can be examined. 1) Physicians. Of the 9 officers and 15 trustees of the American Medical Association in 1966-67, no female names were listed, and 2 officers and 1 trustee were 1 isted by initials only. If we give one of those Initialed names to women, the percentage breakdown would be $96 \%$ male and $4 \%$ female.

The second largest medical association is the American College of Surgeons. Of its officers and administrators, the number of women are shown in Table III.

2) University Professors. Women represented 22 per cent of the faculty and staff in universities and colleges in 1965-66.

3) Dentists. Women represented 2.3 per cent of the dentists in 1960. 4) Natural Scientists. Women represented 6.7 per cent of the natural scientists in 1966 listed in the National Register.

5) Soclal Scientists. Women represented 12.8 per cent of the social scientists iisted in the National Register in 1966. 6) Vetarinarians. The percentage of women as officers of the national and local American Veterinary Medical Associations could not be computed because of the predominate use of initials. 
TABLE III

OFFICERS AND ADMINISTRATORS OF THE AMERICAN

COLLEGE OF SURGEONS, BY SEX, 1967-68

\begin{tabular}{|c|c|c|c|}
\hline Title & Number & Male & Female \\
\hline $\begin{array}{l}\text { Officers, } 1967-68 \\
\text { Officers Elect, 1967-68 } \\
\text { Administrative Staff } \\
\text { Administrative Associates } \\
\text { Board of Regents } \\
\text { Advisory Council } \\
\text { Board of Governors }\end{array}$ & $\begin{array}{r}5 \\
3 \\
8 \\
3 \\
21 \\
11^{\mathrm{a}} \\
199\end{array}$ & $\begin{array}{r}5 \\
3 \\
8 \\
3 \\
21 \\
11 \\
198\end{array}$ & $\begin{array}{l}0 \\
0 \\
0 \\
0 \\
0 \\
0 \\
1_{b}^{b}\end{array}$ \\
\hline Total & 250 & 249 & 1 \\
\hline In Per Cent & 100.0 & 99.6 & .4 \\
\hline
\end{tabular}

${ }^{a}$ Initials of one person.

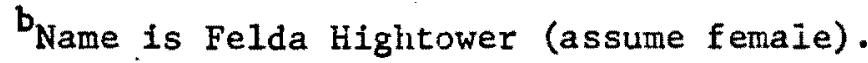

Source: American College of Surgeons, 1968 Directory (Chicago: Lakeside Press, 1968). 
TABLE IV

OFFICERS OF THE AMERICAN ASSOCIATION OF UNIVERSITY PROFESSORS, 1969, AND OF THE AMERICAN ASSOCIATION

OF JUNIOR COLILEES, 1970

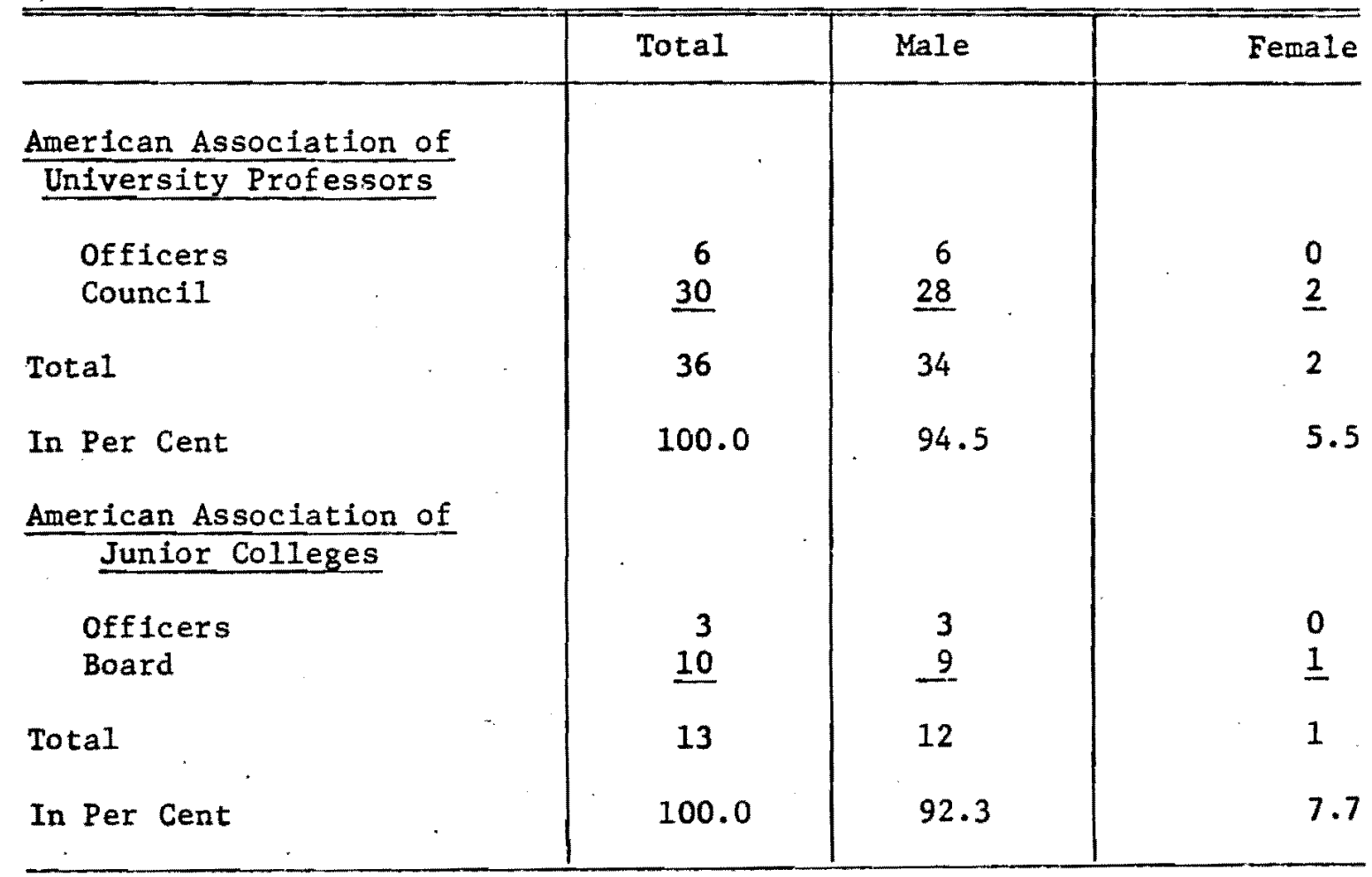

Source: AAUP, American Association of University Professors Bulletin, January, 1970. AAJC, Junior College Journal, 1970. 
TABLE V

OFFICERS OF THE AMERICAN DENTAL ASSOCIATION, BY SEX, 1968

\begin{tabular}{|c|c|c|c|}
\hline Title & Total & Male & Female \\
\hline American Dental Association & & & \\
\hline $\begin{array}{l}\text { Officers } \\
\text { Trustees } \\
\text { Assistant Secretaries } \\
17 \text { Council Chairmen } \\
6 \text { Bureaus }\end{array}$ & $\begin{array}{r}9 \\
14 \\
5 \\
17 \\
6\end{array}$ & $\begin{array}{r}9 \\
14 \\
5 \\
17 \\
6\end{array}$ & $\begin{array}{l}0 \\
0 \\
0 \\
0 \\
0\end{array}$ \\
\hline 50 State Dental Associations & & & \\
\hline A11 Oificers & $270^{a}$ & $268^{\mathrm{b}}$ & $\underline{2}^{b}$ \\
\hline Total & 321 & 319 & 2. \\
\hline In Per Cent & 100.0 & 99.4 & .6 \\
\hline
\end{tabular}

approximately.

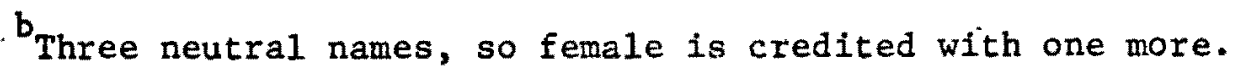

Source: ADA, 1968 American Dental Directory, PP. R47, R50-R57. 
TABLE VI

OFFICERS OF NATURAL SCIENTIFIC ASSOCIATIONS, BY SEX

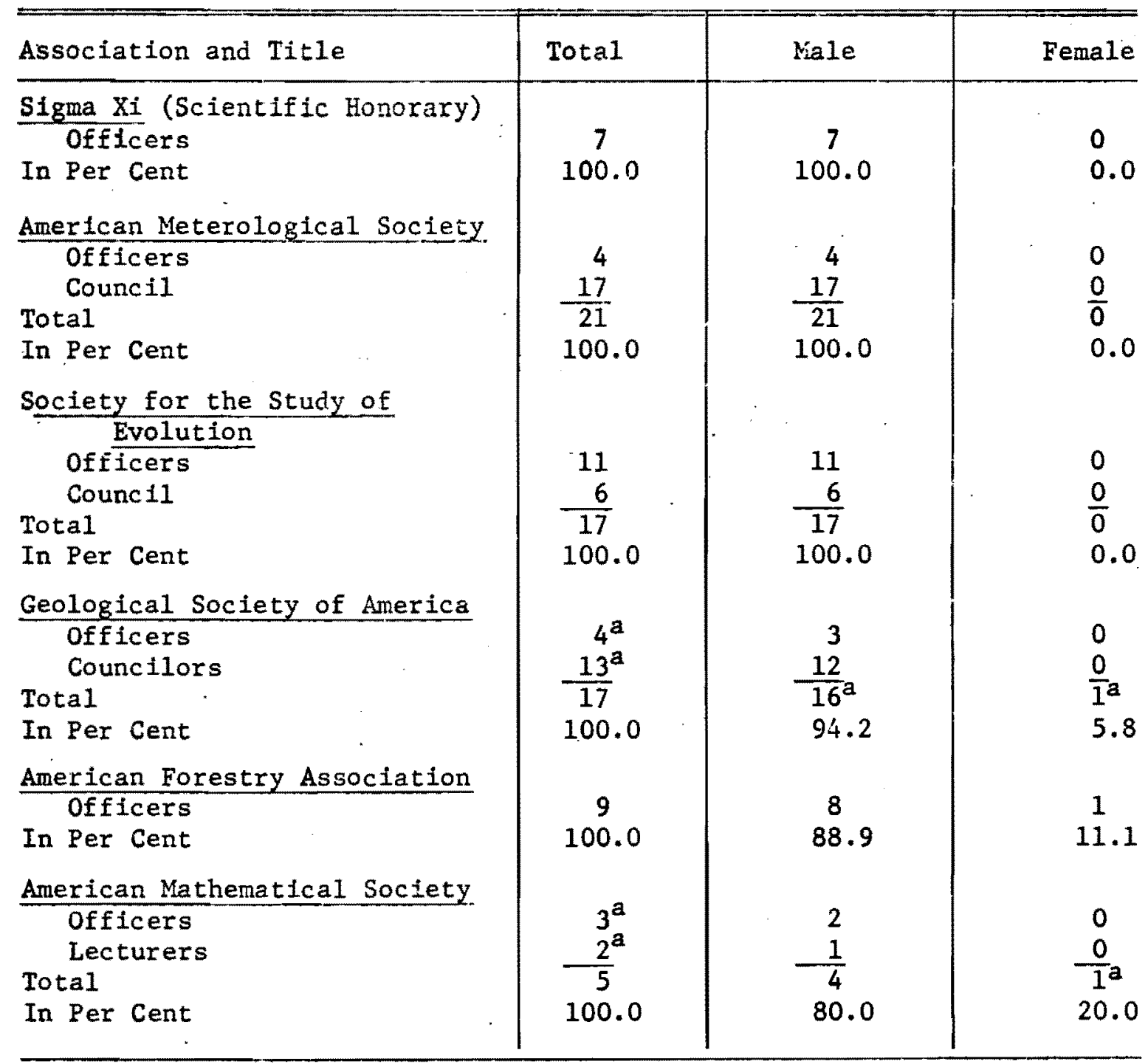
tively.

${ }^{a}$ Includes initials of one person, credit male and female alterna-

Sources: American Scientist, Vo1. 58, No. 2, Mar-Apr, 1970. Bulletin of the American Meteorological Society, Vol. 51, No. 2, Feb., 1970.

Evolution - International Journal of Organic Evolution, Vo1. 23, No. 4, Dec., 1969.

Geological Society of America Bulletin, Vol. 80, No. 11, Nov., 1969.

American Forests, Vo1. 75, No. 1, Jan., 1969.

Bulletin of the AMS, Vo1. 75, No. 6, Nov., 1969. 
TABLE VII

OFFICERS UF THE SOCIAL SCIENTIFIC ASSOCIATIONS, BY SEX

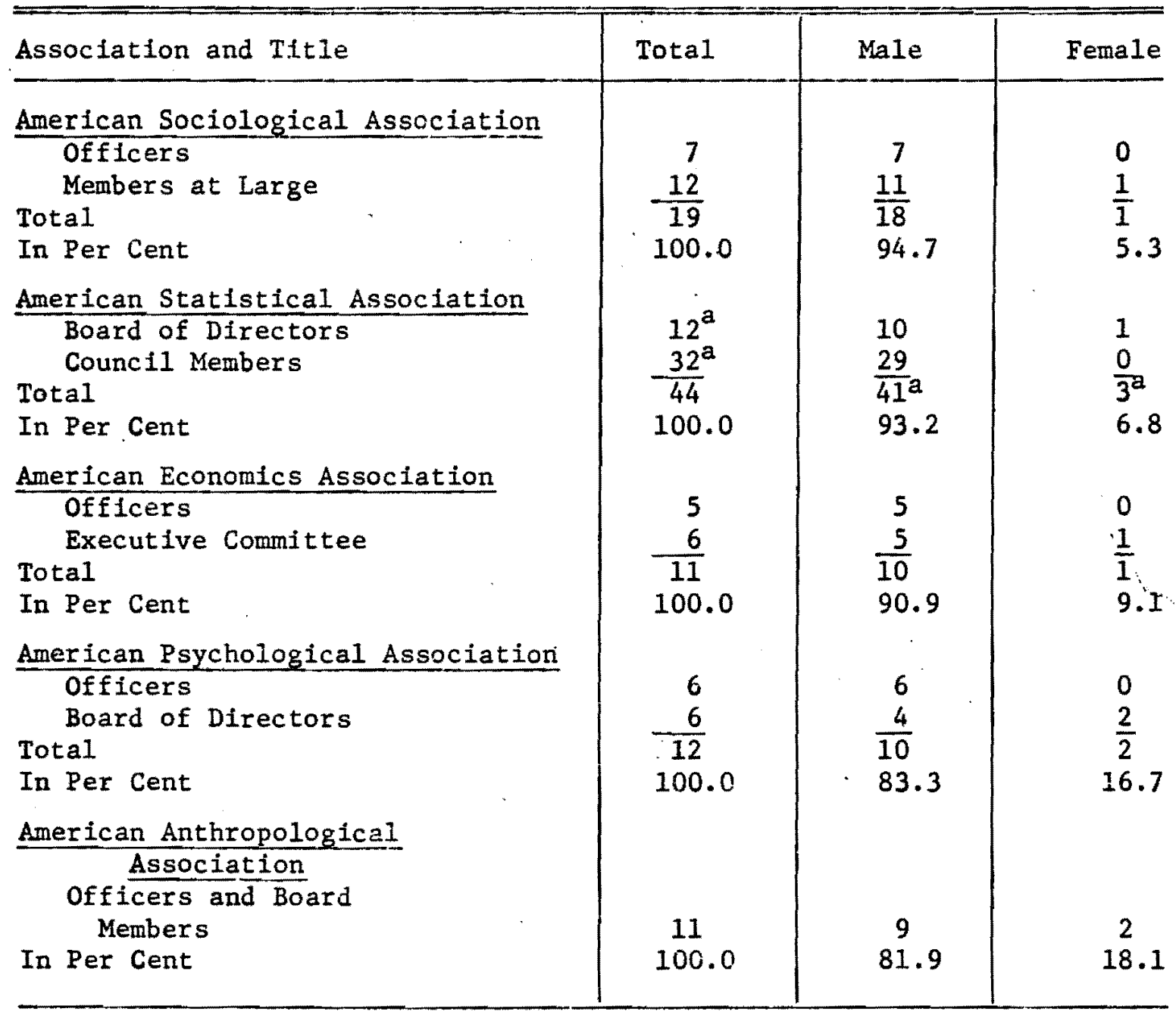

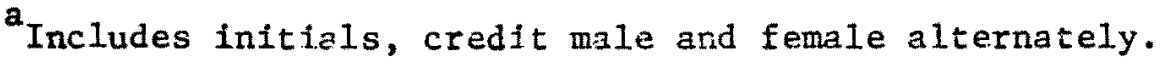

Sources: ASA, American Sociological Review, Feb., 1970. Journal of the American Statistical Association, Vol. 64, No. 326, June, 1969.

The American Economic Review, Vo1. LIX, No. 2, May, 1969. American Psychologist, Vol. 25, No. 2, Feb., 1970, p. 116. American Anthropologist, Vol. 70, No. 4, August, 1968. 
7) Social Workers. Data on officers, by sex, of the professional organization of social workers were not obtainable.

$\mathrm{H}_{3}$ : Women in the professions tend to be in positions isolated from the public and patients/clients.

In order to test this hypothesis, detailed data are necessary on the actual positions held by professionals within each place of employment, the setting of their job and sex. Such information is not avallable. Data concerning type of employer, primary work activity are available for many professions but these are gross categorizations which do not reveal the location of their activity nor their degree of isolation. So from now on this hypothesis will be omitted from the study. It would be a relevant question for future research on newly gathered data. However, there are no data available to test it at this time.

Within the seven professions, only in two do the practitioners tend to be self-employed, medicine and dentistry. Census figures give a general comparison between salaried and non-salaried within these two professions.

A difficulty arises here in that group practice blurs the lines between self-employed and being on salary. As group practitioners, they could consider themselves either on salary as being paid by the partnership or being self-employed as being a partner and, therefore, paying himself. This difficulty would arise more often in the case of men on salary as opposed to women. Women might be less frequently in group practice than men for the reason that collezgueship is so strong in a group practice. The members of a group practice would be more concerned about their image to the public; would have nore control over shom they 
TABLE VIII

PER CENT DISTRIBUTION OF SALARIED AND

SELF-EMPLOYED DENTISTS AND

PHYSICIANS, BY SEX, 1960

\begin{tabular}{l|r|r|r}
\hline \multicolumn{1}{c|}{ Occupation } & Total Number & Male & Female \\
\hline Dentists: & & & \\
Salaried & 8,326 & 8.6 & 53.4 \\
Self-Employed & $\underline{78,784}$ & $\underline{91.4}$ & $\underline{4.6}$ \\
Total & 87,110 & 100.0 & 100.0 \\
Physlcians \& Surgeons: & & & \\
Salarled & & & \\
Self-Employed & 149,881 & 33.3 & 61.0 \\
Total & 230,307 & 100.0 & 100.0 \\
\hline
\end{tabular}

Source: United States Census of Population, Characteristics of Professional Workers, 1960, Table 1 (PC(2)-7E), 1963, p. 1-2.

let into their group; would be more aware because they work so closely that a new kind of person - a woman - would not fit in and could not be counted on to act like a male colleague. From this, one could infer that women listed in the data as being on salary might be in an institutional setting rather than group practice.

In a study of 525 physiclans who once worked in the public health fleld, John Kosa and Robert Coker, Jr. (1965:298) report that at the time of the survey, $73 \%$ of the females and $56 \%$ of the males worked in salaried positions. In addition women spent on the average about seven-tenths of their total full-time work career in salarled positions in contrast to four-tenths for the men. 
Louis Reed (1968:126), in a study on physicians' and dentists'

Incomes, reported the distribution (Table IY) of self-employed and salaried physicians, dentists and veterinarians based on 1960 census data.

TABLE IX

PER CENT DISTRIBUTION OF SALARIED AND

SELF-EMPLOYED PHYSICIANS, DENTISTS

AND VETERINARIANS, BY SEX, 1960

\begin{tabular}{|c|c|c|}
\hline Occupation & Men & Women \\
\hline \multicolumn{3}{|l|}{ Physicians: } \\
\hline $\begin{array}{l}\text { Salaried } \\
\text { Self-Employed } \\
\text { Unpaid Family Worker }\end{array}$ & $\begin{array}{l}33.2 \\
66.8 \\
. \\
\end{array}$ & $\begin{array}{r}60.9 \\
38.3 \\
\quad .8 \\
\end{array}$ \\
\hline Total & 100.0 & $100: 0$ \\
\hline Dentists: & & \\
\hline $\begin{array}{l}\text { Salaried } \\
\text { Self-Employed } \\
\text { Unpaid Family Worker }\end{array}$ & $\begin{array}{r}8.5 \\
91.5 \\
.1 \\
\end{array}$ & $\begin{array}{r}54.0 \\
42.7 \\
3.3 \\
\end{array}$ \\
\hline Total & 100.1 & 100.0 \\
\hline \multicolumn{3}{|l|}{ Veterinarians: } \\
\hline $\begin{array}{l}\text { Salaried } \\
\text { Self-Employed } \\
\text { Unpaid Family Worker }\end{array}$ & $\begin{array}{r}29.3 \\
70.7 \\
- \\
\end{array}$ & $\begin{array}{l}35.6 \\
42.8 \\
21.6 \\
\end{array}$ \\
\hline & 100.0 & 100.0 \\
\hline
\end{tabular}

${ }^{a}$ Less than $0.05 \%$.

Source: Louis Reed, Studies of the Incomes of Physicians and Dentists, U. S. Dept. of Health, Education and Welfare; Social Security Administration (Washington, D. C.: 1968), p. 126 . 
$\mathrm{H}_{5}$ : Women in the professions tend to be in career lines apart from the main streains of promotion to power and prestige.

$\mathrm{H}_{6}:$ If in the same career lines as men, women in the professions tend to fill the lower echelons of a profession while the men advance.

These two hypotheses will be tested on the same data for the reason that they deal with two sides of the same question and for the reason that the focus is on the top positions in each profession. A determination will be made concerning if women are in the same career lines as men or separate career lines on the basis of women's chances of reaching these top positions from the positions they generally occupy in the field. If women are in the same career lines as men; a determination will be made concerning chances of promotion to the higher positions on the basis of the percentage of women in those higher levels compared to their proportion in the field.

Top positions will be determined by using indices of highest incomes, prestige specialties, officers of professional associations, top rank in professions which have set levels of promotion, types of employment and primary work activity.

1) Physicians. The top positions of power and prestige in medicine are difficult to determine because there are many different ways of obtaining power and prestige in the profession and no single route. From the 1iterature I would categorize top positions into 1) those making highest incomes, 2) those in prestige specialties, 3) officers of the American Medical Association, 4) heads of medical schools and 5) chiefs of staff of the best hospitals. Data on women in only the first three categories are obtainable. Distribution of women among faculties of medical schools is Included, however. 
TABLE X

MEDICAL SPECIALTIES, BY IEDIAN INCOMES, PRESTIGE, PER CENT WOMEN AND PER CENT PHYSICIANS

\begin{tabular}{|c|c|c|c|c|}
\hline $\begin{array}{c}\text { Specialty } \\
\text { (1) }\end{array}$ & $\begin{array}{c}\text { Median } \\
\text { Income } \\
1958 \\
(2)\end{array}$ & $\begin{array}{c}\text { Prestige } \\
\text { Rank } \\
1958 \\
(3)\end{array}$ & $\begin{array}{l}\text { Per Cent } \\
\text { Women } \\
1965 \\
(4)\end{array}$ & $\begin{array}{c}\text { Per Cent } \\
\text { Physicians } \\
1962 \\
\text { (5) }\end{array}$ \\
\hline $\begin{array}{l}\text { Urology } \\
\text { Surgery } \\
\text { Obstetrics/Gyn. } \\
\text { Ophthamology } \\
\text { Dermatology } \\
\text { Internal Medicine } \\
\text { Pediatrics } \\
\quad . \\
\text { All Specialists }\end{array}$ & $\begin{array}{r}\$ 29,000 \\
27,900 \\
27,900 \\
24,800 \\
24,800 \\
22,300 \\
20,700 \\
24,800\end{array}$ & $\begin{array}{r}- \\
1 \\
4 \\
7 \\
12 \\
2 \\
7\end{array}$ & $\begin{array}{r}.2 \\
.9 \\
6.2 \\
3.3 \\
6.6 \\
4.7 \\
19.3\end{array}$ & $\begin{array}{r}2.8 \\
20.8 \\
9.0 \\
8.4 \\
2.0 \\
22.0 \\
8.1 \\
100.0 *\end{array}$ \\
\hline
\end{tabular}

*Includes $26,9 \%$ in other specialties not listed in source for Cols. 1 and 2 .

Sources: (1-2) Seynour E. Harris, The Economics of American Medicine (New York: Macmillan Co., 1964), p. 156.

(3) Maryland State Planning Commission, Medical Education and Research Needs in Maryland (Baltimore: State Planning Department, 1962), p. 82.

(4) American Medical Women's Association, The Fuller Utilization of the Woman Physician (Washington, D. C.: Dept. of Labor, 1968), p. 73 .

(5) U. S. Dept. of HEW, Health Manpower Sourcebook, Section 14, "Medical Specialists" (Washington, D.C., 1962), p. 230-33. 
TABLE XI

PRIVATE MEDICAL PRACTITIONERS, BY FIELD, PER CENT WOMEN

1965

\begin{tabular}{l|c|c}
\hline \multicolumn{1}{c|}{ Field } & $\begin{array}{c}\text { Median } \\
\text { Income } \\
(1)\end{array}$ & $\begin{array}{c}\text { Per Cent } \\
\text { Women } \\
(2)\end{array}$ \\
\hline All Surgical Specialties & $\$ 32,950$ & $3.5 *$ \\
General Surgery & 31,540 & .9 \\
All Medical Specialties & 29,050 & 6.9 \\
Obstetrics/Gynecology & 28,400 & 6.2 \\
Internal Medicine & 25,580 & 4.7 \\
Pediatrics & 24,490 & 19.3 \\
General Practice & 24,420 & 5.2 \\
All M. D. 's & 28,380 & 6.1 \\
\hline
\end{tabular}

*Anesthesiology accounts for a large \% of this.

Source: (1) Medical Economics, December 13, 1965.

(2) The Fuller Utilization of the Woman Physician, p. 73, except for All Medical Specialties, my computations. This includes all women physicians, not only private practitiocers. 
TABLE XII

PER CENT DISTRIBUTION OF INCOME

FOR PHYSICIANS, BY SEX

1959

\begin{tabular}{l|r|r}
\hline \multicolumn{1}{c|}{ Total } & Men & Women \\
\hline Less than $\$ 1,000$ to $\$ 4,999$ & 19.5 & 42.5 \\
$\$ 5,000$ to $\$ 9,999$ & 14.6 & 29.0 \\
$\$ 10,000$ to $\$ 14,999$ & 15.3 & 13.4 \\
$\$ 15,000$ or more & 50.7 & 14.9 \\
Total & 100.0 & 100.0 \\
Median Income, 1964 & $\$ 25,879$ & $\$ 16,132$ \\
\hline
\end{tabular}

Source: Distribution: Reed, Incomes of Physicians and Dentists, p. 132 .

Median Income: Carol Lopate, Women in Medicine (Baltimore: Johns Press, 1968), p. 185.

TABLE XIII

PER CENT DISTRIBUTION CLASS OF EMPLOYMENT OF PHYSICIANS, BY SEX 1960

\begin{tabular}{l|c|r}
\hline \multicolumn{1}{c|}{ Total } & Men & Women \\
\hline Wage or Salary: $\begin{array}{l}\text { Private } \\
\text { Government }\end{array}$ & 19.4 & 30.8 \\
Self-Employed & 13.8 & 30.1 \\
Unpaid Family Worker & 66.8 & 38.3 \\
Total & - & .8 \\
\hline
\end{tabular}

Source: Reed, Incomes of Physicians and Dent1sts, p. 126. 
TABLE XIV

TYPE OF PRACTICE OF WOMEN PHYSICIANS, WOMEN AS PER CENT OF TOTAL PHYSICIANS, PER CENT DISTRIBUTION OF WOMEN PHYSICIANS AND ALI. PHYSICIANS

\begin{tabular}{|c|c|c|c|c|}
\hline Type of Practice & $\begin{array}{l}\text { No. of } \\
\text { Women } \\
1965\end{array}$ & $\begin{array}{c}\text { Women as } \% \\
\text { of Total } \\
1965\end{array}$ & $\begin{array}{l}\% \text { Distr. of } \\
\text { Women Physi- } \\
\text { clans, } 1965\end{array}$ & $\begin{array}{c}\% \text { Distr. of } \\
\text { Physicians, } \\
1962\end{array}$ \\
\hline $\begin{array}{l}\text { Private Practice } \\
\text { Training Programs } \\
\text { Full-Time Hospital Svc. } \\
\text { Full-Time Med. School } \\
\text { Fac. } \\
\text { Preventive Med., Admin- } \\
\text { Istration, Research }\end{array}$ & $\begin{array}{r}8,119 \\
4,036 \\
2,236 \\
699 \\
1,864 \\
\end{array}$ & $\begin{array}{r}4.5 \\
9.3 \\
8.0 \\
7.8 \\
11.5 \\
\end{array}$ & $\left.\begin{array}{l}47.9 \\
23.8 \\
13.2 \\
4.1 \\
11.0\end{array}\right\} 28.3$ & $\left\{\begin{array}{l}67.0 \\
15.0 \\
15.0\end{array}\right.$ \\
\hline Total & 16,954 & 6.1 & 100.0 & 100.0 \\
\hline
\end{tabular}

Source: The Fuller Utilization of Woman Physician, p. 66, my computations, and Health Manpower Sourcebook, Section 14 , p. 230 .

TABLE XV

MEMBERS OF 25 MEDICAL SPECIALTY BOARDS, 1968

\begin{tabular}{l|c|c|c}
\hline \multicolumn{1}{c|}{ Title } & Total & Male & Female \\
\hline Officers & 74 & 74 & 0 \\
Board Members & $242^{\mathrm{a}}$ & 241 & 1 \\
Other & $52^{\mathrm{b}}$ & 50 & $\underline{2}$ \\
Total & 368 & 365 & 3 \\
In Per Cent & 100.0 & 99.2 & .8 \\
\hline
\end{tabular}

$a_{2}$ board members 1 isted as initials, credit 1 female.

$b_{1}$ other 1 isted by initials.

Source: Marquis Who's tho, Inc., Directory of Medical Specialists, Vo1. XIII (St. Louis: Von Hoffmann Press, Inc., 1968). 
TABLE XVI

FACULTY OF 78 UNITED STATES MEDICAL SCHOOLS, BY RANK AND SEX, 1965-66

\begin{tabular}{l|r|rr|rr}
\hline \multicolumn{1}{c|}{ Title } & Total & Number $\%$ /Total & \multicolumn{2}{c}{ Female } \\
& 1,047 & 1,034 & 98.8 & 13 & 1.2 \\
\hline Department Chairman & 2,659 & 2,554 & 96.1 & 105 & 3.9 \\
Professor & 3,855 & 3,499 & 9.1 .8 & 356 & 9.2 \\
Associate Professor & 5,467 & 4,774 & 87.3 & 693 & 12.7 \\
Assistant Professor & 367 & 263 & 71.7 & 104 & 28.3 \\
Senior Instructor & 2,902 & 2,132 & 73.5 & 770 & 26.5 \\
Instructor & 337 & 266 & 78.9 & -71 & 21.1 \\
Other of Unknown & 16,634 & 14,522 & 87.3 & 2,112 & 12.7 \\
Total & & & & & \\
\hline
\end{tabular}

Source: Lopate, Women in Medicine, p. 199.

2) University Professors. The top positions of university professors are 1) the top ranks of professors, 2) top administrators, 3) top ranks at top universities, 4) deans of professional schools, and 5) officers of university professors' associations.

Women officers of the American Association of University Professors (Table IV) represent $5.5 \%$ of the total, and approximately $20 \%$ of the total faculty members. Women as officers of the American Association of Junior Colleges (Table V) account for $7.7 \%$ of the total while they represent $32.0 \%$ of the total faculty. 


\section{TABLE XVII}

WOMEN PROFESSORS AS PER. CENT OF TOTAL FACULTY BY TYPE OF INSTITUTION, MEDIAN INCOME AND RANK

\begin{tabular}{|c|c|c|c|c|c|c|c|c|c|c|c|c|}
\hline \multirow[t]{2}{*}{ Type of Institution } & \multirow{2}{*}{$\begin{array}{l}\text { Women } \\
\text { as \% of } \\
\text { Total } \\
\text { Faculty } \\
1954-55 \\
\text { (1) }\end{array}$} & \multirow{2}{*}{$\begin{array}{c}\text { Med Lan } \\
\text { Income } \\
\text { of Fac. } \\
1965-66 \\
\text { (2) }\end{array}$} & \multicolumn{10}{|c|}{$\begin{array}{l}\text { \% Distribution of Faculty among } \\
\text { Academic Ranks, 1963-64 } \\
\text { (3) }\end{array}$} \\
\hline & & & $\begin{array}{c}\text { All } \\
M\end{array}$ & $\begin{array}{c}\text { Ranks } \\
F\end{array}$ & $\begin{array}{c}\text { Profes } \\
M\end{array}$ & $\begin{array}{c}\text { ssors } \\
\text { F }\end{array}$ & $\underset{M}{\text { Assoc }}$ & $\begin{array}{c}\text { Prof. } \\
\text { F }\end{array}$ & $\begin{array}{c}\text { Asst. } \\
M\end{array}$ & $\begin{array}{l}\text { Prof. } \\
\text { F }\end{array}$ & $\begin{array}{c}\text { Instr } \\
M\end{array}$ & $\begin{array}{l}\text { uctors } \\
\text { F }\end{array}$ \\
\hline Al1 Institutions & 21.8 & $\$ 8,583$ & 80.5 & 19.5 & 90.3 & 9.7 & 84.0 & 16.0 & 80.7 & 19.3 & 69.9 & 30.1 \\
\hline $\begin{array}{l}\text { Teachers Colleges } \\
\text { Small Private Coll. } \\
\text { Public Colleges } \\
\text { Medium-size Private }\end{array}$ & $\begin{array}{l}36.8 \\
33.5 \\
29.5\end{array}$ & $\begin{array}{l}\text { no data } \\
6,845 \\
8,750\end{array}$ & $\begin{array}{l}\text { nd } \\
58.2 \\
76.0\end{array}$ & $\begin{array}{c}\text { nd } \\
41.8 \\
24.0\end{array}$ & $\begin{array}{c}\text { nd } \\
69.5 \\
85.4\end{array}$ & $\begin{array}{c}\text { nd } \\
30.5 \\
14.6\end{array}$ & $\begin{array}{c}\text { nd } \\
56.9 \\
78.7\end{array}$ & $\begin{array}{c}\text { nd } \\
43.1 \\
21.3\end{array}$ & $\begin{array}{l}\text { nd } \\
56.7 \\
74.2\end{array}$ & $\begin{array}{c}\text { nd } \\
43.3 \\
25.8\end{array}$ & $\begin{array}{c}\text { nd } \\
47.9 \\
64.7\end{array}$ & $\begin{array}{l}\text { nd } \\
52.1 \\
35.3\end{array}$ \\
\hline $\begin{array}{l}\text { Colleges } \\
\text { Large Private coll. } \\
\text { Public Untversities } \\
\text { Private Universities }\end{array}$ & $\begin{array}{l}25.6 \\
20.4 \\
1.3 .7 \\
13.7\end{array}$ & $\begin{array}{r}7,480 \\
8,214 \\
10,053 \\
10,157\end{array}$ & $\begin{array}{l}66.8 \\
79.9 \\
83.9 \\
87.7\end{array}$ & $\begin{array}{l}33.2 \\
20.1 \\
16.1 \\
12.3\end{array}$ & $\begin{array}{l}74.0 \\
86.7 \\
93.3 \\
95.1\end{array}$ & $\begin{array}{r}26.0 \\
13.3 \\
6.7 \\
4.9\end{array}$ & $\begin{array}{l}68.7 \\
31.8 \\
87.4 \\
89.7\end{array}$ & $\begin{array}{l}31.3 \\
18.2 \\
12.6 \\
10.3\end{array}$ & $\begin{array}{l}67.0 \\
79.8 \\
83.6 \\
87.0\end{array}$ & $\begin{array}{l}33.0 \\
20.2 \\
16.4 \\
13.0\end{array}$ & $\begin{array}{l}57.3 \\
70.6 \\
71.4 \\
72.9\end{array}$ & $\begin{array}{l}42.7 \\
29.4 \\
28.6 \\
27.1\end{array}$ \\
\hline
\end{tabular}

nd: no data.

Sources: (1) John B. Parrish, "Women in Top Level Teaching and Research," AAUW Journal, January, 1962, 99-107.

(2) NEA Research Division, Salarles in Higher Education, 1967-68, p. 1.1.

(3) NEA, Wanted - More Women In Educational Leadership, p. 14, my computations. 
TABLE XVIII

MEAN SALARIES OF FACLITY, BY ACADEMIC RANK,

PER CENT WOMEN IN 18 LEADING UNIVERSITIES

\begin{tabular}{|c|c|c|c|c|c|c|}
\hline \multirow[b]{2}{*}{$\begin{array}{l}\text { Academic } \\
\text { Rank }\end{array}$} & \multicolumn{2}{|c|}{ (1) $1966-67$} & \multicolumn{3}{|c|}{ (2) 18 Top Univer, 1960} & (3) $1963-64$ \\
\hline & $\begin{array}{l}\text { Univer- } \\
\text { sities } \\
\text { Mean } \\
\text { Salary }\end{array}$ & $\begin{array}{c}\text { Other } \\
4-y r . \\
\text { Mean } \\
\text { Salary }\end{array}$ & $\begin{array}{l}18 \\
\text { Univ. } \\
\text { Women as } \\
\% \text { Total }\end{array}$ & $\begin{array}{l}8 \text { Lgst. } 1 \\
\text { Endowm. } \\
\text { Women as } \\
\% \text { Total }\end{array}$ & $\begin{array}{l}10 \text { Lgst. } \\
\text { Enroll. } \\
\text { Women as } \\
\% \text { Total }\end{array}$ & $\begin{array}{c}\text { All } \\
\text { Instructors } \\
\text { Women as } \\
\% \text { Total }\end{array}$ \\
\hline $\begin{array}{l}\text { Professor } \\
\text { Assoc. Prof. } \\
\text { Asst. Prof. } \\
\text { Instructors } \\
\text { Al1 Ranks }\end{array}$ & $\begin{array}{c}\$ 17,376 \\
13,312 \\
10,952 \\
8,452 \\
-\end{array}$ & $\begin{array}{r}\$ 14,280 \\
11,436 \\
9,523 \\
7,572 \\
-\end{array}$ & $\begin{array}{r}3.7 \\
9.3 \\
11.4 \\
16.5 \\
9.9\end{array}$ & $\begin{array}{l}2.6 \\
7.5 \\
8.5 \\
9.8 \\
6.6\end{array}$ & $\begin{array}{r}4.3 \\
10.1 \\
12.7 \\
20.4 \\
11.1\end{array}$ & $\begin{array}{r}9.7 \\
16.0 \\
19.3 \\
\frac{30.1}{19.5}\end{array}$ \\
\hline
\end{tabular}

Source: (1) National Center for Educational Statistics, Higher Education Salaries, $1966-67$, p. 10.

(2) Parrish, "Women in Top Level Teaching and Research," p. 102 .

(3) NEA, Wanted - Women in Educational Leadership, p. 14, my computations.

TABLE XIX

MEDIAN SALARIES OF COLLEGE PRESIDENTS AND DEANS, BY SEX, AND PER CENT DISTRIBUTION OF

INCOME, BY SEX, 1959

\begin{tabular}{l|r|r}
\multicolumn{1}{c|}{ Income } & Male & Female \\
\hline Less than $\$ 1,000$ to $\$ 4,999$ & 12.2 & 32.6 \\
$\$ 5,000$ to $\$ 9,999$ & 39.2 & 52.2 \\
$\$ 10,000$ to $\$ 14,999$ & 29.5 & 13.8 \\
$\$ 15,000$ or more & 19.2 & $\frac{1.4}{100.0}$ \\
Total & 100.1 & $\frac{100}{\$ 6,009.00}$ \\
\hline Median Salaries: & $\$ 9,704.00$ & $\$$ \\
\hline
\end{tabular}

Source: Louis Reed, p. 129, 132. 
TABLE XX

MEAN AND MEDIAN SALARIES OF SELECTED ADMINISTRATIVE PERSONNEL

IN FOUR-YEAR AND TWO-YEAR INSTITUTIONS, BY CONTROL

\begin{tabular}{|c|c|c|c|c|}
\hline \multirow{2}{*}{ Administrative Position } & \multicolumn{2}{|c|}{$\begin{array}{c}\text { Mean Salaries 1966-67 } \\
\text { 4-Year Institutions }\end{array}$} & \multicolumn{2}{|c|}{$\begin{array}{l}\text { Median Salaries 1967-68 } \\
\text { 2-Year Institutions }\end{array}$} \\
\hline & $\begin{array}{l}\text { Public } \\
\text { Control }\end{array}$ & $\begin{array}{l}\text { Private } \\
\text { Control }\end{array}$ & $\begin{array}{l}\text { Public } \\
\text { Control }\end{array}$ & $\begin{array}{l}\text { Private } \\
\text { Control }\end{array}$ \\
\hline $\begin{array}{l}\text { President } \\
\text { Academic Dean } \\
\text { Director of Planning } \\
\text { Dean of Students } \\
\text { Director of Instructional } \\
\text { Studies } \\
\text { Director of Development } \\
\text { Director of Student } \\
\text { Health } \\
\text { Director of Admissions } \\
\text { Director of Athletics } \\
\text { Dean af Men } \\
\text { Registrarc } \\
\text { Director of Public } \\
\text { Relations } \\
\text { Dean of Womenc } \\
\text { Head Librarlan } \\
\text { Director of Non-Academic } \\
\text { Personnel } \\
\text { Director of Food } \\
\text { Services }\end{array}$ & $\begin{array}{l}\$ 23,988 \\
19,461 \\
15,842 \\
15,553 \\
14,555 \\
13,787 \\
13,659 \\
12,718 \\
11,800^{\mathrm{b}} \\
11,786 \\
11,771 \\
11,543 \\
11,338 \\
11,020^{\mathrm{b}} \\
11,013\end{array}$ & $\begin{array}{r}\$ 19,771 \\
15,141 \\
15,243 \\
11,003 \\
13,978 \\
11,977 \\
8,316 \\
9,764 \\
8,979 \\
8,678 \\
9,177 \\
8,011 \\
\\
10,403 \\
8,408\end{array}$ & $\begin{array}{c}11,304^{2} \\
10,786 \\
11,708 \\
10,347 \\
10,222 \\
10,250 \\
10,439 \\
.\end{array}$ & $\begin{array}{l}8,487^{a} \\
8,563 \\
7,375 \\
7,607 \\
8,875 \\
7,813 \\
7,750\end{array}$ \\
\hline
\end{tabular}

$a_{\text {mean }}$ salaries for year 1966-67.

bapproximate median salartes, computed on basis of 1965-66 and 1967-68 median salaries.

' good chances of being a woman in this position.

Source: National Center, Higher Education Salaries, 1966-67, p. 8 . NEA, Salaries in Higher Education, 1967-68, pp. 42, 85-86. 
TABLE XXI

MEDIAN SALARIES OF PROFESSIONAI SCHOOL POSITIONS, 1967-68

Field of School

Medicine. . . . . . . . . . . . . .

Dentistry . . . . . . . . . . . . .

Law . . . . . . . . . . . .....

Veterinary Medicine . . . . . . . . . .

Soclal Welfare. . . . . . . . . . . .

Engineering . . . . . . . . . . . . . .

Agriculture . . . . . . . . . . . . . .

Pharmacy, . . . . . . . . . . . . .

flne Arts..................

Journalism. . . . . . . . . . . . .

Home Economics. . . . . . . . . . . .

Music... . . . . . . . . . . . . .

Physical Education. . . . . . . . . . .
Median Salary

$\$ 30,321$

26,125

24,458

24,250

23,000

22,472

21,650

21,125

20,429

19,083

18,417

17,583

17,500

16,550

Source: NEA, Salaries in Higher Education, 1967-68, p. 46. 
TABLE XXII

WOMEN AS PEK CENT OF FACULTY AND

OTHER PROHESSIONAL STAFF,

1959

Type of Position

Women as Per Cent of Total in Positions

Professional Staff for General

Administration ${ }^{a b}$. . . . . . . . . . .

21.2

Professional Staff for Student

Personnel Services. . . . . . . . . . . . .

44.4

Faculty for Resident Instruction

In Degree-Credit Courses. . . . . . . . . .

19.4

Faculty for Resident Instruction

In Other Than Degree-Credit

Courses . . . . . . . . . . . . . . .

Extension Staff ..................

Other Faculty ..................

22.6

Professional Library Staff. . . . . . . . .

67.2

Professional Staff for Organ-

Ized Research..................

Elementary or Secondary Education . . . . . .

11.4

59.3

a"Women constituted over $1 / 4$ th of the administrators in colleges and unfversities but were concentrated in women's colleges, according to a study made by the National Council of Adninistrative Women in Educa-tion in 1952. Women held about $3 / 4$ ths of the administrative positions in women's colleges and $1 / 5$ th in co-educational colleges. Positions in which $2 / 3$ rds or more of the persons were women included dean of women, director of food service, director of residence, and head librarian. Among other college administrative positions, women were from $1 / 3$ rd to $1 / 2$ of the registrars, bursars, auditors or accountants, and directors of student guidance, health, student activities, practice teaching, alumni contact, and student personnel. Over 9/10ths of the women's colleges and about $2 / 3 \mathrm{rds}$ of the co-educational colleges had women members on their governing boards. However, women were less than $1 / 10$ th of all board members in co-educational colleges having any women on the board, and just over 1/3rd of those in women's colleges" (1962 Handbook on Women Workers, p. 20).

bore recent scatistics show that in 1964 , among presidents of 4year colleges and universities, 117 out of 1495 were women ( $8 \%$ ) but all but 8 were heads of Catholic women's colleges. Further among presidents of 2-year colleges in 1964, 62 out of 644 were women (10\%) but all but 11 were also heads of Catholic women's colieges.

Source: Jessie Bernard, Academic Women (Pennsylvania: Pennsy1vania State University Press, 1964), p. 38-39. NEA, Wanted - Mor E Women in Educational Leadership, p. Iv. 
3) Dentists, The top positions in dentistry I am assuming from the 1iterature are similar to those of physicians. The main differences are that dentists do not enter specialties as frequently as physicians and hospital association is not as frequent among dentists as physicians. As a group, dentists tend to be in general practice much more than physicians, 89\% for dentists in 1958 (Hollinshead, 1961:148) versus 28.5\% for physicians in 1960 (Rayack, 1967:42). Data on highest incomes, prestige specialties, officers of the American Dental Association will now be examined.

TABLE XXIII

MEDIAN INCOMES OF DENTISTS BY TYPE OF PFACTICE AND PER. CENT DISTRIBUTIOION, 1958

\begin{tabular}{l|cc|c|r|c}
\hline \multicolumn{1}{c|}{$\begin{array}{c}\text { Type } \\
\text { of } \\
\text { Practice }\end{array}$} & \multicolumn{2}{|c|}{\begin{tabular}{c} 
All Dentists \\
\cline { 2 - 5 }
\end{tabular}} & $\begin{array}{c}\text { Median-Salaried } \\
\text { Income }\end{array}$ & $\begin{array}{c}\text { Median } \\
\text { Income }\end{array}$ & $\begin{array}{c}\text { Distr. of } \\
\text { of Dentists } \\
\text { Domen } \\
\text { Dentists }\end{array}$ \\
\hline General Practice & $\$ 12,664$ & 5 & $\$ 13,005$ & 89.5 & 58 \\
Specialties & 17,250 & - & 18,983 & $\frac{10.5}{(3.9)}$ & $\frac{31}{(7)}$ \\
Orthodontics & 20,975 & 1 & 23,975 & $(2.4)$ & $(0)$ \\
Oral Surgery & 17,350 & 2 & 17,850 & $(1.0)$ & $(4)$ \\
Periodontics & 16,300 & 3 & $\ldots a$ & $(1.5)$ & $(14)$ \\
Pedodontics & 14,200 & 4 & 16,100 & $(1.7)$ & $(6)$ \\
Other & 12,500 & 6 & 13,600 & - & 6 \\
Teaching & - & - & - & - & 5 \\
Other & - & - & - & & \\
\hline
\end{tabular}

a $_{\text {Too few replies. }}$

Source: Byron S. Hollinshead, The Survey of Dentistry (Wash., D. C.: American Council on Education, 1961), p. 143, 148, 546 . 
TABLE XXIV

PER CENT DISTRIBUTION OF MEDIAN INCOMES OF DENTISTS BY SEX, 1959

\begin{tabular}{l|r|r} 
& & Per Cent Distribution \\
\hline Median Incone & Men & Women \\
\cline { 2 - 3 } & 12.5 & 59.2 \\
$\$ 5,000$ to $\$ 9,999$ & 25.6 & 24.8 \\
$\$ 10,000$ to $\$ 14,999$ & 25.0 & 10.3 \\
$\$ 15,000$ or more & 37.0 & 5.7 \\
Total & 100.1 & 100.0 \\
\hline Median Incomes: & $\$ 11,858$ & $\$ 3,768$ \\
\hline
\end{tabular}

Source: Reed, p. 129, 132. 
TABLE XXV

PRESTIGE OF TYPE OF PRACTICE AND

SPECIALTIES OF DENTISTS,

1958

\begin{tabular}{|c|c|c|c|c|c|}
\hline & $\begin{array}{c}\text { Rank Order of } \\
\text { Practice* }\end{array}$ & & $\begin{array}{l}\text { Rank Order of } \\
\text { Specialty** }\end{array}$ & $\begin{array}{c}\text { Rank by } \\
\% \text { Distr. } \\
\text { of Total Dentists }\end{array}$ & $\begin{array}{l}\text { Rank by } \\
\text { \% Distr. } \\
\text { of Women }\end{array}$ \\
\hline $\begin{array}{l}1 \\
2 \\
3 \\
4 \\
5 \\
6 \\
7 \\
8 \\
9\end{array}$ & $\begin{array}{l}\text { Private Practice } \\
\text { Hospital Staff } \\
\text { Dental Teacher } \\
\text { Group Practice } \\
\text { Armed Forces } \\
\text { Research Worker } \\
\text { Public School } \\
\text { System } \\
\text { U. S. Public } \\
\text { Health Service } \\
\text { State/Local Health } \\
\text { Department } \\
\text { Factory or Plant }\end{array}$ & $\begin{array}{l}1 \\
2 \\
3 \\
4 \\
5 \\
6 \\
7\end{array}$ & $\begin{array}{l}\text { Oral surgery } \\
\text { Ozthodontics } \\
\text { Pedodontics } \\
\text { Prosthodontics } \\
\text { Periodontics } \\
\text { Oral Pathology } \\
\text { Dental Public } \\
\text { Health }\end{array}$ & $\begin{array}{l}2 \\
1 \\
3 \\
5 \\
4 \\
- \\
-\end{array}$ & $\begin{array}{l}- \\
2 \\
1 \\
5 \\
4 \\
- \\
3\end{array}$ \\
\hline
\end{tabular}

*As ranked by students.

**As ranked by faculty.

Source: Hollinshead, p. 546.

TABLE XXVI

TYPE OF EMPLOYMENT OF DENTISTS

BY SEX, 1960

\begin{tabular}{|c|c|c|}
\hline Type of Employment & Men & Women \\
\hline $\begin{array}{l}\text { Wage or Salary: Private } \\
\text { Government } \\
\text { Self-Employed } \\
\text { Unpaid Family Worker }\end{array}$ & $\begin{array}{r}5.5 \\
3.0 \\
91.5 \\
.1 \\
\end{array}$ & $\begin{array}{r}44.1 \\
9.9 \\
42.7 \\
3.3 \\
\end{array}$ \\
\hline Total & 100.0 & 100.0 \\
\hline
\end{tabular}

Source: Reed, P, 126. 
of the officers of the American Dental Association, . $6 \%$ were female in 1968 , compared to approximately $2.3 \%$ women in the total field.

4) Natural.and Social Scientists. The natural and social scientists will be examined together. Top positions of scientists are deternined by highest incomes, by type of specialty, by type of employer, and by primary work activity. Data on sex for the top positions, by specific title, e.g., heads of research departments, higher. levels in non-profit organizations, etc., are not obtainable. So top positions will be inferred, however, from the other indices mentioned above. 
TABLE XXVII

MEDIAN ANNUAL SALARY OF ALL SCIENTISTS, WOMEN SCIENTISTS, BY FIELD AND TYPE OF EMPLOYER, 1966

\begin{tabular}{|c|c|c|c|c|c|c|c|c|c|}
\hline \multirow[b]{2}{*}{ Fleld } & \multirow[b]{2}{*}{ Total } & \multirow[b]{2}{*}{$\begin{array}{c}\text { Women } \\
\text { ScIentists }\end{array}$} & \multicolumn{7}{|c|}{ Type of Employer } \\
\hline & & & $\begin{array}{l}\text { Educ. } \\
\text { Inst. }\end{array}$ & $\begin{array}{l}\text { Fed. } \\
\text { Gov. }\end{array}$ & $\begin{array}{l}\text { Other } \\
\text { Gov. }\end{array}$ & $\begin{array}{c}\text { Nonprof. } \\
\text { Organ. }\end{array}$ & $\begin{array}{l}\text { Ind. \& } \\
\text { Bus. }\end{array}$ & $\begin{array}{l}\text { Self- } \\
\text { Emp1. }\end{array}$ & Other \\
\hline $\begin{array}{l}\text { Chemistry } \\
\text { Earth Sclences } \\
\text { Meteorology } \\
\text { Physics } \\
\text { Mathematics } \\
\text { Agricultural Sclence } \\
\text { Biol. Sclences }\end{array}$ & $\begin{array}{r}\$ 12,000 \\
11,400 \\
11,700 \\
12,500 \\
12,000 \\
10,000 \\
12,000\end{array}$ & $\begin{array}{l}8,100 \\
9,000 \\
9,600 \\
9,000 \\
9,100 \\
8,500 \\
9,200\end{array}$ & $\begin{array}{l}11,000 \\
11,000 \\
12,000 \\
11,000 \\
11,000 \\
12,000 \\
13,100\end{array}$ & $\begin{array}{l}12,000 \\
11,800 \\
11,700 \\
12,900 \\
12,900 \\
10,000 \\
12,500\end{array}$ & $\begin{array}{r}9,700 \\
9,500 \\
10,100 \\
9,300 \\
10,400 \\
8,700 \\
10,400\end{array}$ & $\begin{array}{l}12,000 \\
12,000 \\
14,000 \\
14,400 \\
14,800 \\
12,000 \\
14,000\end{array}$ & $\begin{array}{l}12,800 \\
12,000 \\
12,000 \\
14,600 \\
13,500 \\
10,000 \\
13,900\end{array}$ & $\left|\begin{array}{c}15,000 \\
13,200 \\
- \\
20,000 \\
20,500 \\
11,000 \\
20,000\end{array}\right|$ & $\begin{array}{c}11,500 \\
11,500 \\
- \\
10,000 \\
11,300 \\
- \\
11,000\end{array}$ \\
\hline $\begin{array}{l}\text { Psychology } \\
\text { Statistics } \\
\text { Economics } \\
\text { Sociology } \\
\text { Anthropology } \\
\text { Linguistics } \\
\text { Other }\end{array}$ & $\begin{array}{l}11,500 \\
12,800 \\
13,100 \\
11,300 \\
11,500 \\
10,000 \\
12,000\end{array}$ & $\begin{array}{c}10,000 \\
10,500 \\
10,300 \\
9,600 \\
9,600 \\
8,600 \\
-\end{array}$ & $\begin{array}{l}12,000 \\
13,000 \\
13,000 \\
12,500 \\
13,000 \\
10,500 \\
10,600\end{array}$ & $\begin{array}{l}13,400 \\
14,300 \\
14,700 \\
14,700 \\
15,800 \\
12,000 \\
13,400\end{array}$ & $\begin{array}{c}10,400 \\
10,800 \\
13,000 \\
11,500 \\
- \\
- \\
10,700\end{array}$ & $\begin{array}{c}11,500 \\
13,800 \\
16,200 \\
14,000 \\
- \\
6,000 \\
14,500\end{array}$ & $\begin{array}{c}15,100 \\
13,000 \\
15,300 \\
15,000 \\
- \\
13,800 \\
13,000\end{array}$ & $\left|\begin{array}{c}20,000 \\
- \\
18,000 \\
- \\
- \\
- \\
17,500\end{array}\right|$ & $\begin{array}{c}11,500 \\
- \\
15,000 \\
14,000 \\
10,600 \\
- \\
10,900\end{array}$ \\
\hline All Flelds & 12,000 & 9,000 & 12,000 & 12,100 & 9,900 & 13,000 & 13,000 & 17,000 & 11,500 \\
\hline
\end{tabular}

Source: Amertcan Sclence Manpower 1966, pp. 52, 91-92. 
TABLE XXVIII

MEDIAN ANNUAL SALARIES OF SCIENTISTS, PRIMARY WORK ACTIVITY AND TYPE OF EMPLOYER, 1966

\begin{tabular}{|c|c|c|c|c|c|c|c|c|c|}
\hline \multirow[b]{2}{*}{ Primary Work Activity } & \multirow[b]{2}{*}{ Total } & \multicolumn{8}{|c|}{ Type of Employer } \\
\hline & & $\begin{array}{l}\text { Educ. } \\
\text { Inst. }\end{array}$ & $\begin{array}{l}\text { Fed. } \\
\text { Gov. }\end{array}$ & $\begin{array}{l}\text { Other } \\
\text { Gov. }\end{array}$ & $\begin{array}{l}\text { Nonprof. } \\
\text { Organ. }\end{array}$ & $\begin{array}{l}\text { Ind. \& } \\
\text { Bus. }\end{array}$ & $\begin{array}{l}\text { Self- } \\
\text { Empl. }\end{array}$ & Other & $\begin{array}{l}\text { No } \\
\text { Report }\end{array}$ \\
\hline All Flelds & 12,000 & 12,000 & 12,100 & 9,900 & 13,000 & 13,000 & 17,000 & 11,500 & 12,000 \\
\hline Research \& Development ${ }^{a}$ & 12,000 & 11,700 & 11,700 & 9,800 & 12,500 & 12,500 & 15,000 & 10,600 & 12,000 \\
\hline $\begin{array}{l}\text { Basic Research } \\
\text { Applied Research }\end{array}$ & $\begin{array}{l}12,000 \\
12,100\end{array}$ & $\begin{array}{l}11,400 \\
12,000\end{array}$ & $\begin{array}{l}12,000 \\
11,700\end{array}$ & $\begin{array}{r}10,000 \\
9,600\end{array}$ & $\begin{array}{l}12,000 \\
13,000\end{array}$ & $\begin{array}{l}13,400 \\
12,600\end{array}$ & 15,000 & $\begin{array}{l}10,500 \\
11,500\end{array}$ & $\begin{array}{l}12,000 \\
13,300\end{array}$ \\
\hline Management or Admin. ${ }^{b}$ & 15,600 & 16,600 & 14,200 & 10,800 & 16,800 & 16,500 & 15,000 & 14,000 & 16,200 \\
\hline Mngmt, or Adm, of $R \& D$ & 16,800 & 16,200 & 16,200 & 12,000 & 18,200 & 17,000 & 17,000 & 15,700 & 17,500 \\
\hline Teaching & 9,800 & 11,500 & 11,700 & 9,800 & $1.5,000$ & 11,500 & - & 8,400 & 10,400 \\
\hline Production \& Inspection & 10,500 & 9,000 & 9,900 & 8,400 & 11,100 & 10,800 & 15,000 & 9,800 & 10,000 \\
\hline other & 11,500 & 11,000 & 11,000 & 9,000 & 10,900 & 12,000 & 18,000 & 12,000 & 12,000 \\
\hline
\end{tabular}

ancludes developinent and design.

${ }^{b}$ Includes management and administration, other than Research and Development.

Source: American Sclence Manpower 1966, p. 96. 
- TABLE XXIX

MEDIAN ANNUAL SALARY OF SCIENTISTS BY TYPE OF EMPLOYER AND PER CENI DISTRIBUTION, 1966

\begin{tabular}{l|c|c|c}
\hline \multicolumn{1}{|c|}{ Type of Employer } & $\begin{array}{c}\text { Median } \\
\text { Salary }\end{array}$ & $\begin{array}{c}\% \text { Distr. } \\
\text { Scientists }\end{array}$ & $\begin{array}{c}\% \text { Distr. } \\
\text { Women } \\
\text { Scientists }\end{array}$ \\
\hline Educational Institutions & $\$ 12,000$ & 36 & 48 \\
Federal Government & 12,100 & 10 & 8 \\
Other Government & 9,900 & 3 & 5 \\
Nonprofit Organizations & 13,000 & 4 & 6 \\
Industry and Business & 13,000 & 35 & 2 \\
Self-Employed & 17,000 & 2 & $\frac{2}{100}$ \\
Other & $\$ 12,000$ & $\frac{6}{100}$ & \\
All employers & & & \\
\hline
\end{tabular}

Source: American Science Manpower, p. 43.

TABLE XXX

MEDIAN SALARY OF SCIENTISTS BY FRIMARY WORK ACIIVITY AND PER CENT DISTRIBUTION, 1966

\begin{tabular}{l|c|c|c}
\hline \multicolumn{1}{c|}{ Primary Work Activity } & $\begin{array}{c}\text { Median } \\
\text { Salary }\end{array}$ & $\begin{array}{c}\% \text { Distr. } \\
\text { Scientists }\end{array}$ & $\begin{array}{c}\% \text { Distr. } \\
\text { Women }\end{array}$ \\
\hline Research and Development & $\$ 12,000$ & 33 & 30 \\
Basic Research & $(12,000)$ & $(16)$ & $(16)$ \\
Applied Research & $(12,100)$ & $(13)$ & $(12)$ \\
Management or Administration & 15,600 & 21 & 7 \\
Mngmt. or Adm. of R \& D & $(16,800)$ & $(10)$ & $(3)$ \\
Teaching & 11,500 & 18 & 26 \\
Production and Inspection & 10,500 & 7 & 4 \\
Other & & 11 & 19 \\
All Activities & $\$ 12,000$ & 100 & 100 \\
\hline
\end{tabular}

Source: American Science Manpower, p. 44. 
5) Veterinarians. Top positions of veterinarians are determined by highest Incomes and prestige specialties. The sex of officers of the American Veterinary Medical Association could not be deternined because of the prevalence of using initials in the directory.

\section{TABLE XXXI}

PER CENT DISTRIBUTION OF VETERINARIANS

BY INCOME AND SEX, AND MEDIAN INCOMES, 1959

\begin{tabular}{l|c|c}
\hline \multicolumn{1}{c|}{ Income } & Nale & Female \\
\hline Less than $\$ 1,000$ to $\$ 4,999$ & 18.7 & 43.2 \\
$\$ 5,000$ to $\$ 9,999$ & 37.6 & 56.9 \\
$\$ 10,000$ to $\$ 14,999$ & 25.3 & 0 \\
$\$ 15,000$ or more & 18.3 & 0 \\
Total & 100.0 & 100.0 \\
\hline Median Incomes: & $\$ 8,882$ & $\$ 5,500$ \\
\hline
\end{tabular}

Source: Reed, p. 129, 132.

TABLE XXXII

PER CENT DISTRIBUTION OF VETERINARIANS

BY CLASS OF EMPLOYMENT AND SEX, 1960

\begin{tabular}{l|c|r}
\hline \multicolumn{1}{c|}{ Class of Employment } & Male & Female \\
\hline Wage or Salary: Private & 16.7 & 21.2 \\
Self-Employed Government & 12.6 & 14.4 \\
Unpaid Family Worker & 70.7 & 42.8 \\
Total & $\frac{0}{21.6}$ \\
\hline
\end{tabular}

Source: Reed, p. 126. 
TABLE XXXIII

PER CENT DISTRIBUTION OF MSU VETERINARY GRADUATES

BY SPECIALTY AND SEX, 1939-1965

\begin{tabular}{|c|c|c|c|c|}
\hline \multirow[b]{2}{*}{ Specialty } & \multicolumn{2}{|c|}{$\begin{array}{c}\text { Men } \\
(n=953)\end{array}$} & \multicolumn{2}{|c|}{$\begin{array}{l}\text { Women } \\
(n=50)\end{array}$} \\
\hline & $1939-52$ & $1953-65$ & $1939-52$ & $1953-65$ \\
\hline $\begin{array}{l}\text { Large animal (Including } \\
\text { equine) } \\
\text { Small animal } \\
\text { Mixed (large and small) } \\
\text { Regularoty Vet. Med. } \\
\text { Research and Training } \\
\text { Mngmt., Sales and Svc. } \\
\text { Laboratory animal } \\
\text { Other (specific type } \\
\text { of specialty) } \\
\text { Retired } \\
\text { Employed outside vet. } \\
\text { Not practicing at } \\
\text { present } \\
\text { No response. } \\
\text { Total }\end{array}$ & $\begin{array}{r}4 \\
25 \\
31 \\
10 \\
9 \\
4 \\
1 \\
\\
13 \\
1 \\
1 \\
\\
0 \\
1 \\
100\end{array}$ & $\begin{array}{r}7 \\
35 \\
28 \\
7 \\
8 \\
2 \\
1 \\
\\
13 \\
0 \\
1 \\
\\
0 \\
1 \\
100\end{array}$ & $\begin{array}{r}0 \\
33 \\
5 \\
5 \\
5 \\
0 \\
9 \\
\\
0 \\
0 \\
0 \\
\\
38 \\
5 \\
100\end{array}$ & $\begin{array}{r}0 \\
66 \\
10 \\
3 \\
14 \\
0 \\
0 \\
\\
3 \\
0 \\
0 \\
\\
3 \\
0 \\
\\
100\end{array}$ \\
\hline
\end{tabular}

Source: Betty Giuliani and John Centra, "The Woman Veterinarian," p. 973. 
6) Social Workers. The top positions among social workers are the top ranks within their system. Data on any higher levels among social workers were not obtainable. Table XXXIV shows the distribution of men and women among the levels of social wcrk and their median incomes. Information on age is included in this anaiysis to show that not only are men predominating in the executive positions, but also that they are dolng so at younger ages than women.

TABLE XXXIV

SOCIAL WORKERS, EXCLUDING

RECREATION WORKERS

1960

\begin{tabular}{|c|c|c|c|c|c|c|c|c|}
\hline \multirow{2}{*}{ Position } & \multicolumn{2}{|c|}{ Median Incomes } & \multicolumn{2}{|c|}{$\%$ Distr. } & \multicolumn{2}{|c|}{$\%$ Total } & \multicolumn{2}{|c|}{ Median Age } \\
\hline & $\mathbf{M}$ & $\mathrm{F}$ & $\mathbf{M}$ & $\mathbf{F}$ & $\mathbf{M}$ & $\mathbf{F}$ & $\mathbf{M}$ & $F$ \\
\hline Direct-Service Position & $\$ 5,060$ & $\$ 4,590$ & 53 & 68 & 35 & 65 & - & - \\
\hline $\begin{array}{l}\text { Case Worker } \\
\text { Group Worker } \\
\text { Other Worker }\end{array}$ & $\begin{array}{l}- \\
- \\
-\end{array}$ & $\begin{array}{l}- \\
- \\
-\end{array}$ & $\begin{array}{l}(41) \\
(7) \\
(5)\end{array}$ & $\begin{array}{l}(59) \\
(5) \\
(3)\end{array}$ & $\begin{array}{l}- \\
-\end{array}$ & $\begin{array}{l}- \\
-\end{array}$ & $\begin{array}{l}35 \\
32 \\
38\end{array}$ & $\begin{array}{l}43 \\
36 \\
46\end{array}$ \\
\hline Supervisory Position & 6,520 & 6,050 & 9 & 9 & 40 & 60 & 41 & 48 \\
\hline Executive Position & 7,270 & 5,440 & 29 & 15 & 58 & 42 & 44 & 51 \\
\hline Other Position & 6,310 & 6,300 & 8 & 8 & 42 & $\underline{58}$ & $\underline{43}$ & $\underline{49}$ \\
\hline Al1 Positions & $\$ 5,760$ & $\$ 4,940$ & 100 & 100 & 43 & 57 & - & - \\
\hline
\end{tabular}

Source: Salarjes and Conditions of Social Workers in 1960, p. 24 , 80.

1962 Handbook on Women Workers, p. 92, for median Incomes. 
$\mathrm{H}_{7}$ : Women in the professions tend to specialize in those areas relating to the normatively accepted woman's role.

$\mathrm{H}_{8}$ : Women in the professions which have clients or patients tend to deal with clients or patients of equal or lower status.

Women's prescribed role in the United States refers to that of being a mother, nurturing children, being a wife and helping her husband. If she must work, she is encouraged to pursue teaching, librarianship, nursing, secretarial work and service work, which are related to her nurturing, caring, helping (all people-oriented) and subordinate roles of wife and mother. If a woman enters a profession, one would expect to Find her in these kinds of positions within the profession more often than in other kinds of positions, and more often than men, according to hypothesis number 7 . She would be expected to deal with those of equal or inferior status, such as women and children rather than men. Hypothesis number 8 will be examined in relation to women and children patients/ clients.

These two hypotheses are grouped together because they will be examined, using the same data - data referring to specialization within the professions, type of employment and kind of activity.

1) Physicians. For the type of employment for women physicians compared to men physicians, see Table XIII, p. 51 . 
TABLE XXXV

MEDICAL SPECIALTIES OF WOMEN PHYSICIANS

1965

\begin{tabular}{|c|c|c|}
\hline Specialty & $\begin{array}{l}\% \text { Distri. } \\
\text { Women } \\
\text { Physicians }\end{array}$ & $\begin{array}{c}\text { Women as } \\
\% \text { of Total } \\
\text { Physicians } \\
\text { in Specialties }\end{array}$ \\
\hline $\begin{array}{l}\text { General Practice } \\
\text { Pediatrics } \\
\text { Psychiatry } \\
\text { Internal Medicine } \\
\text { Anestheslology } \\
\text { Obstetrics and Gynecclogy } \\
\text { Pathology } \\
\text { Radiology } \\
\text { Public Health and Prev. Medicine } \\
\text { Ophthamology } \\
\text { General Surgery } \\
\text { Administrative Medicine } \\
\text { Dermatology } \\
\text { Child Psychiatry } \\
\text { Other (12 specialties, al1 less than } \\
\quad 1.0 \%) \\
\quad \text { Total }\end{array}$ & $\begin{array}{r}25.4 \\
17.9 \\
11.9 \\
10.6 \\
7.2 \\
6.2 \\
5.0 \\
2.3 \\
2.2 \\
1.7 \\
1.5 \\
1.4 \\
1.3 \\
1.0 \\
4.4 \\
100.0\end{array}$ & $\begin{array}{r}5.2 \\
19.3 \\
11.7 \\
4.7 \\
14.2 \\
6.2 \\
9.9 \\
4.1 \\
16.0 \\
3.3 \\
.9 \\
6.0 \\
6.6 \\
21.3 \\
- \\
6.1\end{array}$ \\
\hline
\end{tabular}

Source: AMWA, The Fuller Utilization of the Woman Physician, p. 73 .

A study of the female physician in public health by Kosa and Coker (1965:300) based on a sample of 525 physicians who at one point worked in public health, contrasts the per cent of the physicians who were currently working in three specialties. The results are shown in the next table. 
TABLX XXXVI

PER CENT PHYSICIANS IN SELECTED

SPECIALTIES, EY SEX

\begin{tabular}{l|r|r}
\hline \multicolumn{1}{c|}{ Specialty } & Male & Female \\
\hline Pediatrics & 7 & 23 \\
Public Health and Preventive Med. & 22 & 39 \\
Psychiatry & 7 & 18 \\
All other fields & 64 & 20 \\
Total & 100 & 100 \\
\hline
\end{tabular}

Source: Kosa and Coker, p. 300.

For type of practice of physicians by sex, see Table XIV, p. 52 .

2) University Professors. '

TABLE XXXVII

WOMEN AS PER CENT OF TOTAL FULL-TIME TEACHERS,

BY SPECIFIC TEACHING FIELD, 1954-55

\begin{tabular}{l|r|l|r}
\hline \multicolumn{1}{c|}{ Field } & \% Total & \multicolumn{1}{c}{ Field } & \% Total \\
\hline Agriculture & 4.1 & Home Economics & 96.4 \\
Biological Sciences & 14.9 & Industrial Arts & 6.9 \\
$\quad$ Physiology & 28.0 & Journalism & 8.2 \\
Business Commerce & 20.2 & Law & 1.7 \\
Education & 36.9 & Library Science & 71.5 \\
Engineering & .5 & Mathematics & 14.2 \\
English & 28.7 & Philosophy & 4.9 \\
Fine Arts & 26.1 & Physical and Health Ed: & 38.5 \\
Foreign Languages & 27.8 & Physical Sciences & 6.0 \\
Geography & 15.8 & Psychology & 13.4 \\
Health Services & 46.9 & Religion & 7.4 \\
Nursing & 98.4 & Social Sciences & 10.7 \\
Public Health & 45.4 & Others & 38.9 \\
& & All Fields & 22.0 \\
& & & \\
\hline
\end{tabular}

Source: NEA, Teacher Supply and Demand, 1954-55, p. 44 . 
TABLE XXXVIII

PER CENT DISTRIBUTION OF WOMEN FACULTY MEMBERS IN 20 LEADING UNIVERSITIES, BY DISCIPLINE, 1960

\begin{tabular}{|c|c|c|}
\hline \multirow[b]{2}{*}{ Discipline } & \multicolumn{2}{|c|}{$\%$ Distribution of Women } \\
\hline & $\begin{array}{c}10 \mathrm{Hi} \text {. Endowment } \\
\text { Universities } \\
\mathbf{N}=350\end{array}$ & $\begin{array}{c}10 \mathrm{Hi} \text {. Enrollment } \\
\text { Universities } \\
N=934\end{array}$ \\
\hline Al1 Disciplines & 100.0 & 100.0 \\
\hline $\begin{array}{l}\text { Physical Sciences } \\
\text { Astronomy } \\
\text { Chemistry } \\
\text { Geology } \\
\text { Physics }\end{array}$ & $\begin{array}{l}3.4 \\
0.3 \\
1.7 \\
0.3 \\
1.1\end{array}$ & $\begin{array}{l}1.9 \\
0.2 \\
0.9 \\
0.1 \\
0.7\end{array}$ \\
\hline $\begin{array}{l}\text { Biological Sciences } \\
\text { Anatomy } \\
\text { Bacteriology } \\
\text { Blochemistry } \\
\text { Botany } \\
\text { Physiology } \\
\text { Zoology }\end{array}$ & $\begin{array}{r}10.9 \\
2.6 \\
1.7 \\
2.0 \\
0.6 \\
1.4 \\
0.6\end{array}$ & $\begin{array}{l}5.9 \\
1.3 \\
0.6 \\
0.2 \\
0.7 \\
1.0 \\
0.7\end{array}$ \\
\hline $\begin{array}{l}\text { Social Sciences } \\
\text { Anthropology } \\
\text { Economics } \\
\text { History } \\
\text { Political Science } \\
\text { Sociology }\end{array}$ & $\begin{array}{l}9.7 \\
0.9 \\
2.6 \\
3.1 \\
1.4 \\
1.7\end{array}$ & $\begin{array}{l}5.4 \\
0.1 \\
1.9 \\
1.6 \\
6.6 \\
1.1\end{array}$ \\
\hline $\begin{array}{l}\text { Humanities } \\
\text { English and Literature } \\
\text { Foreign Language and Literature } \\
\text { Fine and Applied Arts } \\
\text { Music } \\
\text { Philosophy }\end{array}$ & $\begin{array}{r}19.4 \\
5.1 \\
8.3 \\
3.4 \\
2.0 \\
0.6\end{array}$ & $\begin{array}{r}19.0 \\
6.1 \\
5.1 \\
1.8 \\
5.4 \\
0.5\end{array}$ \\
\hline $\begin{array}{l}\text { Selected Other Fields } \\
\text { Education } \\
\text { Engineering } \\
\text { Geography } \\
\text { Home Economics } \\
\text { Law } \\
\text { Library Science } \\
\text { Mathematics } \\
\text { Psychology }\end{array}$ & $\begin{array}{r}27.1 \\
0.3 \\
0.0 \\
20.6 \\
0.6 \\
2.6 \\
2.3 \\
3.1\end{array}$ & $\begin{array}{r}25.3 \\
0.3 \\
0.2 \\
33.2 \\
0.2 \\
2.0 \\
4.2 \\
2.5\end{array}$ \\
\hline
\end{tabular}

Source: Parrish, p. 107. 
3) Dentists. As was mentioned earlier, general practice is more predominant among dentists than physicians. The specialties are not as significant a part of dentistry as medicine. However, women dentists speclalize more than men, proporticnately. See Table XXVI, p. 61, for type of employment of dentists, and Table XXIII, p. 59, for type of practice and specialties.

4) Natural and Social Scientists.

TABLE XXXIX

PER CENT DISTRIBUTION OF SCIENTISTS

BY FIELD AND SEX, 1966

\begin{tabular}{|c|c|c|c|}
\hline Field & Men & Women & $\begin{array}{l}\text { Women as } \\
\% \text { Total }\end{array}$ \\
\hline Chemistry & 27 & 25 & 8 \\
\hline Earth Sclences & 8 & 3 & 3 \\
\hline Meteorology & 3 & 1 & 2 \\
\hline Physics & 13 & 5 & 3 \\
\hline Mathematics & 9 & 12 & 10 \\
\hline Agricultural Sciences & 4 & .2 & .4 \\
\hline Biological Sciences & 12 & 16 & 11 \\
\hline Psychology & 7 & 21 & 22 \\
\hline Statistics & 1 & 2 & 10 \\
\hline Economics & 6 & 3 & 4 \\
\hline Sociology & 1 & 3 & 16 \\
\hline Anthropology & - & 1 & 19 \\
\hline Linguistics & - & 1 & 21 \\
\hline Other & 7 & 7 & 8 \\
\hline Total, All Fields & 100 & 100 & 8 \\
\hline
\end{tabular}

Source: American Science Ianpower 1966. 
TABLE XL

PER CENT DISTRLBUTION OF SCIENTISTS BY FIELD, SEX AND TYPE OF EMPLOYER

1966

\begin{tabular}{l|r|r|r}
\hline \multicolumn{1}{c|}{ Type of Employer } & $\begin{array}{r}\text { \% Distr. } \\
\text { of Total }\end{array}$ & $\begin{array}{r}\% \text { Distr. } \\
\text { of Men }\end{array}$ & $\begin{array}{r}\text { \% Distr. } \\
\text { of Women }\end{array}$ \\
\hline All Types & 100.0 & 100.0 & 100.0 \\
Educational Institutions & 36.0 & 34.9 & 47.9 \\
Federal Government & 10.2 & 10.4 & 7.8 \\
Other Government & 3.4 & 3.3 & 5.0 \\
Military & 2.4 & 2.6 & .3 \\
Non-profit Organizations & 4.0 & 3.8 & 6.5 \\
Industry and Business & 34.6 & 36.5 & 13.2 \\
Self-Employed & 2.0 & 2.0 & 2.2 \\
Other & $: 5$ & .5 & 1.0 \\
Not Employed & 6.1 & 5.3 & 14.9 \\
No Report & .7 & .7 & 1.2 \\
& & & \\
\hline
\end{tabular}

Source: American Science Manpower 1966, pp. 79-81, 200, my computation.

TABLE XLI

PER CENT DISTRIBUTION OF SCIENTISTS BY FIELD, SEX AND PRIMARY WORK ACTIVITY

1966

\begin{tabular}{l|c|c|c}
\hline \hline \multicolumn{1}{c|}{ Primary Work Activity } & $\begin{array}{c}\text { \% Distr. } \\
\text { of Tota1 }\end{array}$ & $\begin{array}{c}\text { \% Distr. } \\
\text { of Men }\end{array}$ & $\begin{array}{c}\text { \% Distr. } \\
\text { of Women }\end{array}$ \\
\hline All Activities & 100.0 & 100.0 & 100.0 \\
Research and Development & 33.3 & 33.6 & 30.0 \\
$\quad$ Basic Research & $(15.8)$ & $(15.7)$ & $(16.3)$ \\
Applied Research & $(12.8)$ & $(12.9)$ & $(11.7)$ \\
Management or Administration & 20.6 & 21.8 & 6.7 \\
Mngmt. or Adm. of R \& & $(10.1)$ & $(10.7)$ & $(2.7)$ \\
Teaching & 18.4 & 17.7 & 26.2 \\
Production and Inspection & 6.8 & 7.0 & 3.7 \\
Other & 11.0 & 10.8 & 13.6 \\
Not Employed & 6.1 & 5.3 & 14.9 \\
No Report & 3.9 & 3.8 & 4.8 \\
& & & \\
\hline
\end{tabular}

Source: American Science Manpower 1966, pp. 85-87, 201, my computation. 


\section{TABLE XLII}

PER CENT DISTRIBUTION OF WOMEN SCIENTISTS

BY FIELD AND TYPE OF EMPLOYER

1966

\begin{tabular}{|c|c|c|c|c|c|c|c|c|c|c|c|c|}
\hline \multirow[b]{3}{*}{ Fleld } & \multirow{2}{*}{\multicolumn{2}{|c|}{$\begin{array}{l}\text { Total } \\
\text { Women } \\
\end{array}$}} & \multicolumn{10}{|c|}{ Type of Employer } \\
\hline & & & \multirow{2}{*}{$\begin{array}{l}\text { Educ. } \\
\text { Inst. }\end{array}$} & \multirow{2}{*}{$\begin{array}{l}\text { Fed. } \\
\text { Gov. }\end{array}$} & \multirow{2}{*}{$\begin{array}{l}\text { Other } \\
\text { Gov. }\end{array}$} & \multirow{2}{*}{$\begin{array}{l}\text { Mili- } \\
\text { tary }\end{array}$} & \multirow{2}{*}{$\begin{array}{c}\text { Nonprof. } \\
\text { Organ. }\end{array}$} & \multirow{2}{*}{$\begin{array}{l}\text { Ind. \& } \\
\text { Bus. }\end{array}$} & \multirow{2}{*}{$\begin{array}{l}\text { Self- } \\
\text { Empl: }\end{array}$} & \multirow[b]{2}{*}{ Other } & \multirow{2}{*}{$\begin{array}{l}\text { Not } \\
\text { Emp1. }\end{array}$} & \multirow{2}{*}{$\begin{array}{c}\text { No } \\
\text { Report }\end{array}$} \\
\hline & No. & $\%$ & & & & & & & & & & \\
\hline Al1 Fields & 20,164 & 100.0 & 47.9 & 7.8 & 5.0 & .3 & 6.5 & 13.2 & 2.2 & 1.0 & 14.9 & 1.2 \\
\hline Chemistry & 4,995 & $|100.0|$ & 35.6 & 8.5 & 1.9 & .2 & 6.0 & 24.5 & .4 & .6 & 21.4 & 1.0 \\
\hline Earth Sciences & 654 & 100.0 & 42.2 & 16.2 & 5.4 & .8 & 2.3 & 9.5 & 3.8 & .3 & 18.8 & .8 \\
\hline Meterology & 129 & 100.0 & 25.6 & 30.2 & 3.1 & 17.8 & 5.4 & 6.2 & - & - & 11.6 & - \\
\hline Phystcs & 981 & 100.0 & 49.8 & 8.6 & .4 & - & 3.6 & 12.8 & .7 & .3 & 22.7 & 1.0 \\
\hline Mathematics & 2,395 & 100.0 & 51.4 & 7.1 & 1.4 & .2 & 3.3 & 22.0 & .8 & .6 & 12.6 & .7 \\
\hline Agric. Sciences & & 100.0 & 48.0 & 14.0 & 18.0 & - & - & 4.0 & 6.0 & - & 10.0 & - \\
\hline Biol. Sciences & 3,347 & 100.0 & 58.2 & 8.3 & 4.0 & .4 & 3.4 & 5.9 & 1.1 & .6 & 12.0 & 1.2 \\
\hline Psychology & 4,233 & 100.0 & 48.5 & 4.4 & 13.4 & .2 & 10.6 & 1.9 & 7.0 & 2.0 & 10.0 & 1.8 \\
\hline Statistics & 307 & 100.0 & 30.0 & 26.7 & 7.5 & - & 4.9 & 19.5 & 1.0 & 1.0 & 9.1 & .3 \\
\hline Economics & 571 & 100.0 & 43.4 & 18.0 & 7.4 & - & 3.5 & 12.3 & 1.1 & .4 & 12.8 & 1.2 \\
\hline Sociology & 581 & 100.0 & 71.8 & 4.5 & 4.3 & - & 4.1 & 1.0 & 1.4 & 2.2 & 8.4 & 2.2 \\
\hline Anthropology & 171 & 100.0 & 73.7 & 1.8 & 1.8 & - & 3.5 & - & 2.9 & 5.3 & 9.9 & 1.2 \\
\hline Linguistics & 267 & 100.0 & 60.7 & 3.4 & 1.1 & - & 9.0 & 3.4 & .7 & .4 & 19.5 & 1.9 \\
\hline Othẹr. & 1,483 & 100.0 & - & - & - & - & - & - & - & - & - & - \\
\hline
\end{tabular}

Source: American Sclence Manpower 1966, from Table A-61, p. 200. 
TABLE XLII

A

PER CENT DISTRIBUTION OF ALL SCIENTISTS

BY FIELD AND TYPE OF EMPLOYER 1966

\begin{tabular}{|c|c|c|c|c|c|c|c|c|c|c|c|c|c|}
\hline \multirow[b]{2}{*}{ Fleld } & \multicolumn{3}{|c|}{ Total Sclentists } & \multicolumn{10}{|c|}{ Type of Employer } \\
\hline & Number & $\begin{array}{c}\% \\
\text { Women }\end{array}$ & $\begin{array}{c}\% \\
\text { Total }\end{array}$ & $\begin{array}{l}\text { Educ. } \\
\text { Inst. }\end{array}$ & $\begin{array}{l}\text { Fed. } \\
\text { Gov. }\end{array}$ & $\begin{array}{r}\text { Other } \\
\text { Gov. }\end{array}$ & $\begin{array}{l}\text { M111- } \\
\text { tary }\end{array}$ & $\begin{array}{c}\text { Nonprof. } \\
\text { Organ. }\end{array}$ & $\begin{array}{c}\text { Ind. } \& \\
\text { Bus. }\end{array}$ & $\begin{array}{l}\text { Self- } \\
\text { Empl. }\end{array}$ & Other & $\begin{array}{c}\text { Not } \\
\text { Empl. }\end{array}$ & $\begin{array}{c}\text { No } \\
\text { Report }\end{array}$ \\
\hline A11 Fle1ds & 242,763 & 8 & 100.0 & 36.0 & 10.2 & 3.4 & 2.4 & 4.0 & 34.6 & 2.0 & .5 & 6.1 & .7 \\
\hline Chem1stry & 65,917 & 8 & 100.0 & 22.4 & 6.0 & 1.3 & 1.0 & 2.9 & 56.2 & .8 & .5 & 8.1 & .7 \\
\hline Earth Sclences & 19,749 & 3 & 100.0 & 23.7 & 13.5 & 4.5 & 1.3 & 1.2 & 41.7 & 7.7 & .3 & 5.7 & .5 \\
\hline Meteorology & 6,283 & 2 & 100.0 & 12.9 & 29.2 & 1.8 & 37.4 & 3.1 & 10.5 & $: 3$ & .4 & 3.9 & .4 \\
\hline Physics & 29,130 & 3 & 100.0 & 45.1 & 10.8 & .4 & 2.0 & 3.5 & 28.4 & .4 & .2 & 8.7 & .6 \\
\hline Mathematics & 22,806 & 10 & 100.0 & 40.8 & 6.2 & 1.2 & 2.0 & 4.7 & 39.0 & .6 & .5 & 4.4 & .5 \\
\hline Agric. Sclences & 10,038 & .4 & 100.0 & 25.4 & 36.8 & 16.7 & .5 & 1.1 & 15.2 & 1.9 & .2 & 1.9 & .4 \\
\hline B1o1. Sctences & 29,633 & 11 & 100.0 & 56.2 & 11.1 & 3.6 & 2.7 & 7.4 & 10.7 & 2.3 & .5 & $4 \cdot 5$ & 1.0 \\
\hline Psychology & 19,027 & 22 & 100.0 & 51.5 & 7.2 & 11.6 & 1.1 & 9.0 & 7.1 & 5.9 & 1.4 & 3.9 & 1.3 \\
\hline Statistics & 3,042 & 10 & 100.0 & 30.8 & 20.2 & 4.1 & 1.4 & 4.9 & 33.3 & .8 & .8 & 3.3 & .5 \\
\hline Economles & 13,150 & 4 & 100.0 & 42.6 & 10.3 & 3.7 & .7 & 3.5 & 31.0 & 1.7 & .3 & 5.5 & .7 \\
\hline Soc1ology & 3,640 & 16 & 100.0 & 75.5 & 4.5 & 3.9 & .3 & 5.8 & 2.4 & .7 & 1.4 & 3.7 & 1.9 \\
\hline Anthropology & 919 & 19 & 100.0 & 78.5 & 4.5 & 1.5 & .1 & 3.6 & .2 & .7 & 5.9 & 4.5 & .7 \\
\hline Linguistics & 1,269 & 21 & 100.0 & 70.1 & 4.6 & 1.4 & .3 & 6.6 & 3.4 & .3 & .6 & 11.5 & 1.2 \\
\hline other & 18,160 & 8 & 100.0 & 26.0 & 5.8 & 1.8 & 2.0 & 2.5 & 52.9 & 1.7 & .7 & 6.0 & .6 \\
\hline
\end{tabular}

Source: American Sclence Manpower 1966, from Table A-12, pp. 79-81. 
TABLE XLIII

PER CENT DISTRIBUTION OF WOMEN SCIENTISTS

BY FIELD AND PRIMARY WORK ACTIVITY

1966

\begin{tabular}{|c|c|c|c|c|c|c|c|c|c|c|c|c|}
\hline \multirow[b]{3}{*}{ Fleld } & \multirow{2}{*}{\multicolumn{2}{|c|}{$\begin{array}{l}\text { Total } \\
\text { Women }\end{array}$}} & \multicolumn{10}{|c|}{ Primary Work Activity } \\
\hline & & & \multicolumn{3}{|c|}{ Res. and Dev. } & \multicolumn{2}{|c|}{ Mngmt. \& Admin. } & \multirow[b]{2}{*}{$\begin{array}{l}\text { Teach- } \\
\text { ing }\end{array}$} & \multirow[b]{2}{*}{$\begin{array}{l}\text { Prod. } \& \\
\text { Insp. }\end{array}$} & \multirow[b]{2}{*}{ Other } & \multirow[b]{2}{*}{$\begin{array}{c}\text { Not } \\
\text { Empl. }\end{array}$} & \multirow[b]{2}{*}{$\begin{array}{c}\text { No } \\
\text { Report }\end{array}$} \\
\hline & No. & $\%$ & $\operatorname{Total}^{a}$ & $\begin{array}{c}\text { Basic } \\
\text { Res. }\end{array}$ & $\begin{array}{l}\text { Appl. } \\
\text { Res. }\end{array}$ & $\operatorname{Total}^{\mathrm{b}}$ & of $R \& D$ & & & & & \\
\hline A11 Flelds & 20,164 & 100.0 & 30.0 & 16.3 & 11.7 & 6.7 & 2.7 & 26.2 & 3.7 & 13.6 & 14.9 & 4.8 \\
\hline Chemistry & 4,995 & 100.0 & 40.2 & $27 \cdot 4$ & 10.4 & 3.8 & 1.7 & 14.3 & 8.3 & 5.7 & 21.4 & 6.2 \\
\hline Earth Sc1. & 654 & 100.0 & 23.2 & $14 \cdot 7$ & 8.3 & 5.4 & 2.4 & 28.1 & .9 & 19.1 & 18.8 & $4 \cdot 4$ \\
\hline Meteorology & 129 & 100.0 & 34.1 & 20.9 & 1.3 .2 & 7.8 & 2.3 & 8.5 & - & 34.1 & 11.6 & 3.9 \\
\hline Physics & 981 & 100.0 & 35.8 & 23.1 & 10.6 & 3.0 & 1.7 & 29.4 & 1.2 & 4.2 & 22.7 & 3.8 \\
\hline Mathematics & 2,395 & 100.0 & 24.1 & 4.6 & 11.0 & 5.4 & 2.5 & 41.0 & 6.9 & 6.8 & 12.6 & 3.3 \\
\hline Agr1c. Sc1. & 50 & 100.0 & 16.0 & 6.0 & 10.0 & 16.0 & 6.0 & 12.0 & 36.0 & 8.0 & 10.0 & 2.0 \\
\hline BLo1. Sc1, & 3,347 & 100.0 & 39.0 & 29.4 & 9.4 & 6.1 & 2.5 & 29.0 & 2.2 & 6.7 & 12.0 & 5.0 \\
\hline Psychology & 4,233 & 100.0 & 25.2 & 5.4 & 19.6 & 10.2 & 2.8 & 17.2 & - & 33.3 & 10.0 & 4.0 \\
\hline Stat1st1cs & 307 & 100.0 & 37.8 & 7.5 & 24.1 & 12.4 & 8.8 & 16.6 & 9.5 & 10.7 & 9.1 & 3.9 \\
\hline Economics & 571 & 100.0 & 23.8 & 8.9 & 14.2 & 15.1 & 8.6 & 31.7 & 1.8 & 10.9 & 12.8 & 4.0 \\
\hline Soctology & 581 & 100.0 & 21.3 & 14.1 & 7.2 & 12.4 & 7.6 & 48.7 & - & 4.1 & 8.4 & 5.0 \\
\hline Anthropology & 171 & 100.0 & 22.2 & 21.1 & 1.2 & 4.7 & 4.1 & 52.0 & - & 6.4 & 9.9 & 4.7 \\
\hline Lingulstics & 267 & 100.0 & 16.9 & 10.9 & 6.0 & 5.6 & 2.6 & 45.3 & - & 9.0 & 19.5 & 3.7 \\
\hline Other & 1,483 & 100.0 & 5.1 & 1.5 & 7.2 & 6.7 & 2.2 & 44.9 & 16.9 & 20.0 & 15.6 & 6.0 \\
\hline
\end{tabular}

ancludes Development and Design.

' Includes Management and Administration, other than $R \& D$.

Source: American Sclence Manpower 1966, from Table A-62, p. 201 
TABLE XLIII

A.

PER CENT DISTRIBUTION OF ALL SCIENTISTS

BY FIELD AND PRIMARY WORK ACTIVITY

1966

\begin{tabular}{|c|c|c|c|c|c|c|c|c|c|c|c|c|c|}
\hline \multirow[b]{3}{*}{ Field } & \multirow{2}{*}{\multicolumn{3}{|c|}{$\begin{array}{c}\text { Total } \\
\text { Scientists }\end{array}$}} & \multicolumn{10}{|c|}{ Prime Work Activity } \\
\hline & & & & \multicolumn{3}{|c|}{ Res. and Dev. } & \multicolumn{2}{|c|}{ Mngmt. \& Admin. } & \multirow[b]{2}{*}{$\begin{array}{c}\text { Teach- } \\
\text { Ing }\end{array}$} & \multirow[b]{2}{*}{$\begin{array}{l}\text { Prod. \& } \\
\text { Insp. }\end{array}$} & \multirow[b]{2}{*}{ Other } & \multirow[b]{2}{*}{$\begin{array}{l}\text { Not } \\
\text { Empl. }\end{array}$} & \multirow[b]{2}{*}{$\begin{array}{l}\text { No } \\
\text { Report }\end{array}$} \\
\hline & Number & $\begin{array}{c}\% \\
\text { Women } \\
\end{array}$ & $\begin{array}{c}\% \\
\text { Total }\end{array}$ & Totala & $\begin{array}{c}\text { Basic } \\
\text { Res. }\end{array}$ & $\begin{array}{l}\text { App1. } \\
\text { Res. }\end{array}$ & Total $b$ & of $R \& D$ & & & & & \\
\hline All Fields & 242,763 & 8 & 100.0 & 33.3 & 15.8 & 12.8 & 20.6 & 10.1 & 18.4 & 6.8 & 11.0 & 6.1 & 3.9 \\
\hline Chemistry & 65,917 & 8 & 100.0 & 41.1 & 19.4 & 14.2 & 19.7 & 12.5 & 9.1 & 13.4 & 3.6 & 8.1 & 5.0 \\
\hline Earth Sci. & 19,749 & 3 & 100.0 & 18.8 & 10.3 & 8.4 & 17.6 & 6.0 & 15.8 & 2.8 & 35.7 & 5.7 & 3.6 \\
\hline Meteorology & 6,283 & 2 & 100.0 & 20.5 & 10.4 & 9.7 & 25.3 & 7.5 & 4.9 & 1.2 & 40.6 & 3.9 & 3.7 \\
\hline Physics & 29,130 & 3 & 100.0 & 50.0 & 28.6 & 15.7 & 14.3 & 10.5 & 20.3 & .8 & 2.9 & 8.7 & 3.1 \\
\hline Mathematics & 22,806 & 10 & 100.0 & 31.1 & .9 & 12.4 & 19.3 & 9.8 & 27.6 & 7.4 & 7.8 & 4.4 & 2.3 \\
\hline Agric. Sc1. & 10,038 & .4 & 100.0 & 25.1 & 6.8 & 16.9 & 49.9 & 10.8 & 8.0 & 3.1 & 7.9 & 1.9 & 4.1 \\
\hline Biol. Sci. & 29,633 & 11 & 100.0 & 41.0 & 27.9 & 12.6 & 16,3 & 9.2 & 24.5 & 1.8 & 7.5 & 4.5 & 4.4 \\
\hline Psychology & 19,027 & 22 & 100.0 & 23.8 & 8.4 & 14.8 & 18.5 & 6.1 & 22.0 & .1 & 28.7 & 3.9 & 3.0 \\
\hline Statistics & 3,042 & 10 & 100.0 & 29.0 & 6.5 & 18.6 & 24.1 & 12.0 & 18.4 & 12.6 & 10.2 & 3.3 & 2.5 \\
\hline Economfes & 13,150 & 4 & 100.0 & 17.3 & 4.9 & 11.3 & 28.5 & 9.9 & 28.3 & 8.5 & 8.3 & 5.5 & 3.5 \\
\hline Sociology & 3,640 & 16 & 100.0 & 26.8 & 13.1 & 8.6 & 17.5 & 9.1 & 48.9 & .3 & 4.0 & 3.7 & 3.7 \\
\hline Anthropology & 919 & 19 & 100.0 & 22.1 & 20.1 & 2.0 & 11.9 & 7.5 & 52.1 & - & 5.2 & 4.5 & 4.2 \\
\hline Linguistics & 1,269 & 21 & 100.0 & 18.4 & 12.0 & 6.3 & 12.2 & 3.5 & 49.5 & - & 5.7 & 11.5 & 4.7 \\
\hline other & 18,160 & 8 & 100.0 & 19.0 & 2.0 & 7.4 & 25.3 & 11.9 & 19.9 & 14.8 & 10.7 & 6.0 & 4.3 \\
\hline
\end{tabular}

${ }^{a}$ Includes Development and Design.

${ }^{b}$ Includes Management and Admintstration, other than $R \& D$.

Source: American Science Manpower 1966, from Table A-14, pp. 85-87. 
5) Veterinarians. Specialization of women veterinarians centers around sma11 animals, research and teaching, according to Giuliani and Centra (1968:975). For their list of specialties and the distribution, see Table XXXIII, p. 67 .

TABLE XIIV

PER CENT DISTRIBUTION OF VETERINARIANS BY TYPE OF EYPLOYMENT AND SEX, 1960

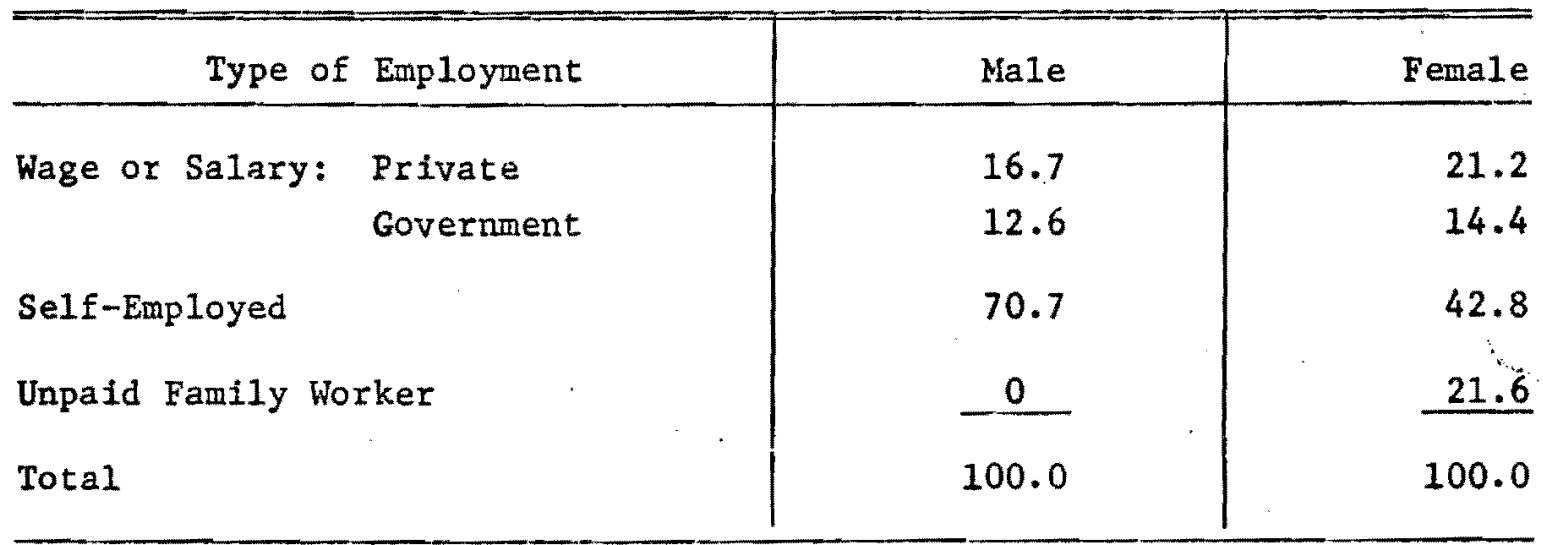

Source: Reed, p. 126. 
6) Social Workers.

TABLE XIV

PER CENT DISTRIBUTION OF SOCIAL WORKERS

IN DIRECT SERVICE POSITIONS,

EXCLUDING RECREATION,

1960

\begin{tabular}{|c|c|c|c|}
\hline Field & Total & Men & Women \\
\hline Caseworkers & 84 & 77 & 87 \\
\hline $\begin{array}{l}\text { Family Service } \\
\text { Child Welfare } \\
\text { Psychiatric Socia]. Worker } \\
\text { Medical Social Worker } \\
\text { School Social Worker }\end{array}$ & $\begin{array}{l}(48) \\
(20) \\
(8) \\
(4) \\
(3)\end{array}$ & $\begin{array}{l}(45) \\
(20) \\
(8) \\
(2) \\
(2)\end{array}$ & $\begin{array}{l}(50) \\
(20) \\
(7) \\
(6) \\
(4)\end{array}$ \\
\hline Group Workers & 10 & 14 & 7 \\
\hline Other Workers & 7 & 9 & 5 \\
\hline $\begin{array}{l}\text { Recreation } \\
\text { Community Organization } \\
\text { Other }\end{array}$ & $\begin{array}{l}\dot{a} \\
(3) \\
(3)\end{array}$ & $\begin{array}{l}(4) \\
(4) \\
\end{array}$ & $\begin{array}{l}\dot{a} \\
(2) \\
(3)\end{array}$ \\
\hline Total & 100.0 & 100 & 100 \\
\hline
\end{tabular}

a Less than $0.5 \%$.

Source: Salaries and Conditions of Social Workers in 1960. 


\section{CHAPTER VII}

\section{DISCUSSION}

$\mathrm{H}_{1}$ : Women tend to be in the professions in smaller proportions than men.

From the data it is safc to say women are represented in the professions in smaller proportions than men, except for soclal work, which is In process of changing to professional standing and may be in process of reversing the proportion of men to women. In Table II, p. 38, data from the 1960 Census show that women represent from $2.1 \%$ to $25.2 \%$ of those in the six top professions with which we are concerned. In the seventh, social work, they predominate with $52.8 \%$ of the total $(57 \%$ of the total, if group workers are included). Social work is one of those considered "in process" of becoming a profession and it is interesting to note that it may also be "in process" of beconing a male-dominated profession. In the decade between 1950 and 1960 men in social work have increased by $84 \%$ in all positions, while women have increased $23 \%$. Men have been encouraged to enter social. work, have been promoted at an earlier age than women, and make more money than women at the same level.

One of the reasons women are in smaller percentages in the professions than men may be that they are avoiding the impact of having an inconsistent status. The Census data show that $66 \%$ of the women in "Professional, Technical and Eindred Workers" are in the five traditional "female" occupations of nursing, teaching, dietetics, librarianship and soclal work. Women account for $79 \%$ of those working in these combined 
fields. Men predominate in all other professional and semi-professional fields.

$\mathrm{H}_{2}$ : Women in the professions do not participate fully in the colleague-group.

No data could be located to show the percentage of women in the professions contrasted with their particlpation rate in professional organizations. There are some indications in the literature that professionals attempt to restrict participation by women, using a $5 \%$ quota system for women in medical schools, and in using strlcter selectjon criterla for women applicants to medical school than for men (Kosa and Coker, '1965:295).

In examining women as officers of professional organizations, for physicians, women were represented as approximately $4 \%$ of the officers. of the American Medical Association in 1966-67, and .4\% of the officials of the American College of Surgeons in 1968. The one female listed there .was in the lowest echelon of officers, 1.e., the board of governors. For professors, women represented $5.5 \%$ of officials in the American Association of University Professors (AAUP) in 1969 with the two women on the council rather than as officers. In the American Association of Junior Colleges (AAJC) one woman on the board represented $7.7 \%$ of the top positions in 1970. These figures contrast with women representing approximateiy $22 \%$ of faculty menbers in colleges and universities.

In the American Dental Association, one woman was treasurer of a local association and the most they can represent is $.6 \%$, which contrasts with women representing $2.3 \%$ of all dentists.

For the professional associations of the natural scientists, a few of the many associations were examined (see Table VI, p. 43). Women 
were not represented among Sigma X1 officers, compared to women's $8 \%$ representation of al1'scientists. In the one biology association, Society for the Study of Evolution, no women were officers while they do account for $11 \%$ of all biologists. No women officers in the American Meteorological Society were found, compared to their $2 \%$ representation in that field. No female names appeared in the American Mathematical Soclety or the Geological Society of America, but because of names with initials, they could represent $20.0 \%$ and $5.8 \%$ of the officers, respectively. These figures are greater than women's $10 \%$ and $3 \%$ of those in mathematics and earth sclences. In the American Forestry Association, one female name appeared on the list of officers, which represents $11.1 \%$ of the officers. Women are found in very small numbers in agricultural sciences and I do not have the breakdown for forestry, specifically. It appears that women in forestry may particlpate quite fully in their colleague-group.

For the social scientists (Table VII, p. 44), women were represented on the lists of officers of professional associations in greater numbers than in the natural sclences but were not in greater propoition to their representation in each field. One woman sociologist accounted. for $5.3 \%$ of the officers in contrast to women's $16 \%$ representation in the field. Two women on the board of directors of the American Fsychological Association accounted for $16.7 \%$ of the officers compared to thelr $22 \%$ in psychology. The most women could represent among officers of the American Anthropological Soclety and the American Statistical Association is $18.1 \%$ and $6.8 \%$ respectively. Women anthropologists represent $19 \%$ of all anthropologists and women statisticians represent $10 \%$ of those In statistics. Finally, the American Economics Association listed 
one woman on the executive comittee, which accounts for $9.1 \%$ of al1 the officers, compared with women as $4 \%$ of all economists. As with forestry and maybe mathematics and geology, women economists may participate fully in their colleague-group, as tested by women attaining the top positions of the professional organizations.

The veterinary medical association used initials and could not be included in this discussion. And a list of officers could not be obtained on the professional organization of social workers.

So it appears that the tendency is for those in the professional associations to elect men rather than women in most cases as their officers and as members of councils and boards. Exceptions were found, however, in forestry and economics, and maybe in mathematics and geology, where women attained top positions within the professional association $\cdots$ in greater proportion than their representation in the field.

$\mathrm{H}_{3}$ : Women in the professions tend to be in positions isolated from the public and patients/clients, where relevant.

This hypothesis could not be tested on the available data.

$\mathrm{H}_{4}$ : Women in the professions tend to be salarled rather than self-employed, where there is a choice.

This hypothesis is borne out for physictans and dentists; considerably more women than men in these occupations tend to be on salary than to be self-employed. Even women veterlnarians show this tendency. Tables VIII and IX, pp. 46-47, show these differences based on 1960 census data.

There are many reasons why this tendency appears to be so strong. One is the attempt to reduse the inpact of being a woman in a man's profession. Other reasons concern shorter working hours, less demands on 
outside time, less interest on the part of women in making high incomes, and closeness of salaried positions, rather than independent practice, to women's tradtional role of beling subordinate and dependent.

$H_{5}$ : Women in the professions tend to be in career lines apart from the mainstreans of promotion to power and prestige.

$\mathrm{H}_{6}$ : If in the same career lines as men, women in the professions tend to fill the lower echelons while the men advance.

An accurate breakdown of the redical specialties most preferred and bringing in the highest income is not available, so this hypothesis Is tested on what I could find. The speclalties with the highest median income in medicine seen to be surgery, urology, surglcal speclalties and obstetrics/gynecology (from Tables X and XI, pp. 49-50). Women phys1clans tend to be considerably under-represented in these speclalties $(.9 \%, .2 \%, 3.5 \%$, respectively) except for $6.2 \%$ in obstetrics/gynceology. Women physicians are over-represented (meaning in greater proportion than their $6.1 \%$ average for the profession) in pediatrics, anesthesiology, psychiatry, child psychlatry and public health and preventive medicine (Table Xxxv, p. 70).

Aside from specialties, women tend to go into general practice, which is 1isted as having the lowest median income of the private practitioners in Table XI, p. 50. Women physicians are also found in larger proportion than average in medical training programs, medical school faculties and preventive medicine, administration and research (Table XIV, p. 52). They represent $4 \%$ of the officers in the AMA and $.4 \%$ in the ACS. Finally, women represent $12.7 \%$ of the faculty of medical schools but only $1.2 \%$ of the total number of department chairmen and $3.9 \%$ of the full professors in medical schools. 
The woman physician tends to be on salary considerably more time than the male physician (Table XIII, p. 51) and nakes considerably less (Table XII, p, 51). By not being in the spectalties with the highest income and prestige and being on salacy more often, women may tend to be In career lines apart from promotion to power and prestige. On the other hand, the woman physician is over-represented on faculties (same career lines as men) and fills the lower echelons in academic ranking. Women university professors represent $21.8 \%$ of all faculty in all institutions. They are over-represented in teachers' colleges ( $36.8 \%$ ) and under-represented in both the public and private universities (13.7\%) as shown in Table XVII, p. 54. They are over-represented among instructors and under-represented as full professors. There appears to be an inverse relationship between academic ranking and percentage of women among faculty and between median income of faculty and percentage of women among faculty. In cther words, women unfversity professors tend to f 111 the lower echelons in academia. In the 18 leading universities, women's proportion is even smaller, $3.7 \%$ of the professors, $16.5 \%$ of the instructors. This is considerably lower than their overall $22 \%$ average. Also, women college presidents and deans have a riedian income less than that of men, $\$ 6,009$ to $\$ 9,704$ in 1959 (Table XIX, p. 55). Median incomes for administrative positions likely to be held by women, e.g., head librarians, deans of women, director of food services, constitute the lower levels for median incomes of administrative positions (Table XX, p. 56). Median Incomes of deans of separately organized professional schools ranked from highest to lowest show those deans likely to be women ranked at the lowest eni (Table XXI, p. 57). Finally, women represented a small number of officers of the professional associations 
but it is difficult to know how powerful and prestigeful (or even large) these are, even though the ones considered may be the main professional associations.

The position of women university professors tends to support both hypotheses numbers 5 and 6 . Women university professors are in career iines apart, to the extent that they are concentrated in flelds whose top positions are neither powerful, prestigeful, nor bring high incomes, e.g., education, home economics, nursing, librartanship. However, in other fields women professors tend to be in the lower echelons within the academic ranking, filling instructorships and teaching in colleges with lower prestige.

Soldd statistics on dentists were not obtainable so these results are more tentative than others. It is interesting that women tend to specialize more than men in dentistry. Specialties bring the higher median incomes, but yet women's median incomes are considerably less than for men dentists $(\$ 11,858$ for men compared to $\$ 3,768$ for women in 1959, as shown in Table XXIV, p. 60). The spread of incomes is also lower for women. Approximately $84 \%$ of the women dentists made less than $\$ 10,000$, whereas $62 \%$ of the men made over $\$ 10,000$ in 1959 . Orthodontia brings the highest income with oral surgery second (out of six approved speclalties). Women dentists were represented in largest numbers in pedodontics ( $43 \%$ of the female specialists), next in orthodontics $(7 \%)$. However, women tend to be salaried considerably more of ten than men ( $54 \%$ women on salary varsus $8.5 \%$ men on salary in 1959 ) and work shorter hours. These conditions would tend to bring down their incomes. Women were also found in dental teaching, which brings one of the lowest salaries in the field. Concerning prestige, one ranking was given by a 
dntal faculty of a college (Table XXV, p. 61) in which private practice and hospital staff were the top two preferred types of practices. Dental teaching was third. Among preferred specialties, dental students in one survey ranked oral surgery first, with orthodontics second (Table XXV, p. 61). There were no women dentists listed as oral surgeons in 1958; $7 \%$ of such women were in orthodontics.

From this discussion, then, top positions in dentistry are specialists in private practice. Dental teaching is given prestige but no money, relatively speaking. Women dentists tend to be salarled, both as specialists and as general practitioners. They tend not to be officlais In the ADA (.6\% in 1968). The data is not sufficiently detalled enough, however, to differentiate between women dentists who are in different career lines from those in lower echelons. To the extent that women are salaried, they are likely to be in separate career lines. To the extent that they specialize more but bring in lower median incomes, they may be said to be filling lower echelons. $\mathrm{H}_{6}$ is also supported by the fact that female dentists tend to work part-time; thus filling the peripheral needs of the profession.

The only data avallable on the natural. and social scientists is taken from the National Register, whose categories do not indicate the very top positions. To sumarize the detailed tables on the scientists here, highest level positions are likely to be determined by median incomes. The top three in each category thus will be 1 isted, with the percentage of women in each of those categories: 
Field w/highest median income, \% women

1 Economics

2 Statistics

3 Physics

Work activity w/highest median income, \% woinen

1 Mngmt, of R\&D $2.3 \%$

2 Mngmt. of Admin. 2.7

$3 R \& D$ Applied 7.6
Employer $w /$ highest median income, \% women

1 Self-Employed $9.0 \%$

2 Industry \& Bus.

3 Non-Profit Org. 13.4

Ph.D.'s w/highest median income, \% women

1 Meteorology

$2.0 \%$

2 Physics

2.1

3 Chemistry

From the percentages in these four areas, women do not tend to be in the higher levels of science to any great extent. Women scientists tend to go into teaching and research (accounting for $56 \%$ of the women scientists). Women tend to go into chemistry, psychology, biology and mathematics (accounting for $74 \%$ of the women scientists). Women scientists represent a greater proportion than their $8 \%$ average for all fields, in psychology, linguistics, anthropology and sociology, biological sclences, mathematics and statistics. From data on their median imcomes (Table XXVII, p. 63) women tend to make, on the average, $\$ 3,000$ less than the average for all. scientists. It appears that women scientists cluster around certain types of activities (teaching and research) and one employer (educational institutions), but are spread throughout several of the natural and social. sciences. In most cases, women do not tend to reach the top positions in professional organizations.

In relation to whether women are in the same career lines as men in sclence, it seems that, regardless of the field, women occupy certain types of positions which bring in less income, and do not have the opportunfty in those positions to reach the higher income levels. Therefore, they may be considered in separate career lines from men. However, on 
the basis of entering many scientific fields instead of a few and bringIng in lower median incomes within each field, they may only be considered to be in lower echelons of each of the different fields.

For veterinarians, positions bring the highest incomes, as determined by Giuliana and Centra (1968:973), are in commercial sales and service, and in equines. According to this study, women do not tend to enter these areas (Table XXXIII, p. 67). Concerning type of employment, women veterinarians tend to be salaried and not working $(52.2 \%)$, compared to men (29.3\%) (Table XXXII, p. 66), tend to work part-time (38\%) compared to men (14\%), and consequently, bring in a lower median income $(\$ 5,500)$ compared to men $(\$ 8,882)$ (Table XXXI, p. 66). A more detalled breakdown of specialties, median incomes and distribution by sex could not be obtained and this one study is a comparatively small sample. But from Giuliana and Centra's study, it seems that women are concentrated in a few areas - small animals, research and teaching - whereas men are more spread out. Consequently, career lines for women veterinarians are likely to be limited and they would tend to be apart from promotion to power and prestige. For those women who are in the same specialties as men - mixed, regulatory - it is not known whether or not they fill the lower echelons.

The career lines of men and women in social work seem to be similar, in that the ranking system is standardized. Top positions outside of the system would probably include heads of schools of soclal work. However, no data on that is available by sex. Table XXXIV, p. 68, shows the distribution of people among the ranks of social work. Although men are a minority, at one point they represent a majority - 58\% of the executive positions (top) are filled by men. Women fill more of the lowest posttions (65\%) - direct service positions, case workers - than men (35\%). 
At the same levels, men earn a higher median income than women, with an overall median income of $\$ 5,760$ to $\$ 4,940$ for female social workers. The biggest discrepancy between median income is on the executive position level (the level where they are the majority), where men make an average of $\$ 830$ more than women. The areas of specialization are not that detailed nor different frow each other to show whether men and women social workers tend to be in different career lines, in support of $\mathrm{H}_{5}$. However, $\mathrm{H}_{6}$ is supported in that women fill the lower echelons to a certain extent, make less money and hold fewer top positions. These data reflect that the men tend to advance over the women.

$H_{7}$ : Women in the professions tend to specialize in those areas relating to the normatively accepted women'\$ role.

$\mathrm{H}_{8}$ : Women in the professions which have clients or patients tend to deal with clients or patients of equal or lower status.

Specialization of women professionals reveals that women do try to enter and are allowed into areas which are more compatible with the female role. We have already seen in the discussion on career lines that women tend to be in few of the many available areas, tend to fill the lower echelons, and tend to be on salary. In discussing these three hypotheses, these findings will be taken into consideration.

1) Physicians. Concerning women's role, Table XXXV, p. 70, shows women physicians specializing, aside from in the areas of general practice, but mainly in psychiatry and child psychiatry, pediatrics, public health and general preventive mediciue, and anestheslology. Helping people with their problems and caring for children are drectly in accord with the social role as wife and mother. Specializing in the public health field, 
according to Kosa and Coker $(1968: 302-304)$, appeals mainly to those who want to avoid the "entrepreneurial competitiveness" that prevails in private practice, for men as well as women. For the woman pliysician, workIng in public health means working on an assured income basis, with regular hours, a manageable work load, and possibly with colleagues whose values are similar to hers (more people-oriented than money-oriented). Thus, here she can easily regulate her role and dutles at home with such a job.

For the specialty of anesthesiology, although a highly skilled job, it seems to be closely related to the nursing occupation where helping the surgeon is the main task. The proportion of women physicians in obstetrics/gynecology, which is the same as the overall average in medicine, is surprising. From the initial discussion of social segregation, it seemed likely that women physicians would tend to specialize in female disorders and obstetrics. However, why women would not tend to go into this specialty in larger numbers can only be guessed; it may reflect the public's prejudice and women's own prejudice against women handling really serious problems. Other than obstetrics/gynecology, the specialties relating closest to women's role are the ones women physicians go into more frequently.

Concerning type of practice, women physicians tend to be on salary more than men (Table III, p. 40), which is in accord with the dependent and subordinate role expected of women. Women physicians tend not to be in surgery, which demands a very dominant, aggressive type of role (Table X, p. 49). Therefore, the medical profession tends to support $\mathrm{H}_{7}$ by allowing women into areas and women physicians choosing areas which are in accord with their female role in our society. 
$\mathrm{H}_{8}$, concerning slients of inferior or equal status as tested on those with women and chiluren clients, is relevant for the medical profession. Of the 30 specialties, three are related to women and children, and women physicians have a higher percentage in two of these than in any other specialty (child psychiatry and pediatrics). Obstetrics/gynecology does not tend to support this hypothesis. It is clear, however, that women physicians predominately go into a few of the many specialties. If it is not ciosely associated with the woman's traditional role, one alternative interpretation is that her wale colleagues designate certain areas of specialization as approved for women. Kosa and Coker (1968:300) show that a woman's medical career choices change over time to fit the allowable alternatives. If this is true, women may tend to select those she is encouraged to choose. Data were not presented to test this notion.

2) University Professors. It was found that most women who work on the higher levels in the economy work in traditionally "female" occupations. It follows that women professors would tend to concentrate in teaching areas associated with those female occupations - nursing, education, social work, dietetics, library science. In fact, these areas account for over half of all women on faculties (Table XXxvII, p. 71). The woman's role is closely associated with these areas 10 gically, and women professors might tend to teach in them. in greater proportion.

Women faculty members in all. colleges and universities in 1954-55 represented greater than a majority in nursing, home economics, and library science. Next greatest percentages were found in public health, physical and health education, education, fóreign languages, English, music, speech and drama, and physiology. The remaining fields were dis- 
tributed in smaller percentages than the $2.2 \%$ average for all fields (Table XXXVII, p. 71). Most of these disciplines above have to do with education or health. Music and drama and the fine arts field, however, have traditionally been associated with women's role of entertaining and performing for others.

In the leading unfversities, Parrish's study (Table XXXVIII, p. 72) shows that women faculty members follow a general pattern, although they are conslderably fewer in number in the top universities. They tend to enter education, home economics, the humanitles, and to be absent from the physical sciences, engineering and law.

To summarize, women faculty members tend to follow the traditional feminine fields associated with women's role, although this is compounded by the fact that teaching itself is considered a normatively accepted role for women. Hence, anong the different disciplines, one would expect to find women teaching in educational institutions rather than in business, Industry, governient, etc. However, at the higher professional levels in universities, women's proportionate representation is greatly reduced. It is reduced even further, if education and home economics are omitted from consideration - from $9 \%$ of the faculty to $5 \%$ in the 18 leading universities (Parrish, 1968:106).

3) Dentists. Women dentists who specialize go into pedodontics and orthodontics most frequently. Women dentists tend to go into teaching and public health areas proportionately more often than do men dentists. These conclusions follow the general pattern found in the other professions. Both pedodontics and orthodontics are speclalties related to children; they are the only child specialties in dentistry. Teaching 
and public health also nay be assoclated with women's role and approved activities. This data on dentistry thus tends to support $\mathrm{H}_{7}$ and $\mathrm{H}_{8}$. Within general practice, some dentists may tend to treat only children, while still being considered general practitioners. Since there is no data on this, it would be interesting to find out what the breakdown by sex is for this kind of practice.

4) Natural and Social Scientists. Women scientists tend to represent a larger proportion in the social sciences than in the natural sciences and enter the social sciences in a larger proportion than in the natural sciences. Psychology is the most popular field for women and is probably assoclated (as with psychiatry) with women's socio-emotional role. The other people-oriented fields - anthropology, sociology, IInguistics hold the next largest percentages of women in the field.

The "hard" sciences reflect an under-representation for women, except In mathematics and the biological sciences. By comparing the percentage of women in educational institutions by field (Table XLII, p. 75), we find that a proportionately larger number of women in educational Institutions are in biological sclences and in mathematics. Consequently, this larger representation of women in these fields may be accounted for by the need for teachers at the lower, undergraduate levels of college teaching (e.g., beginning mathematics and general blology).

By type of employer, women scientists again tend to be in educational institutions in all the sciences. By primary activity, they tend mainly to teach and to do research (Tables XLIII, p. 77, and XLII, p. 75). TeachIng is closely related to wonen's prescribed role and research, in particular research assistants, is related to woman's helping, cubordinate role. 
5) Veterinarians. As with some of the other professions, women veterInarians' speciajties center around a few select areas - small animals and mixed animals - and research and teaching, along with their being on salary. Consequently, for the same reasons mentioned in the previous sections, data on veterinary medicine tend to support both Hypotheses numbers 7 and 9.

6) Social Workers. Details on specialties of social work reveal that women are found in casework more often than men, with family, medical and school casework predominant. However, they go into child welfare work in equal proportions to men and into psychiatrj.c social work in slightly less proportions. The entire field of social work may be considered an approved kind of occupation for women, so all the specialties are related to the kinds of activities with which a woman is usually associated (children, health, school, family, psychlatry). It has been a predominately female field (at least until 1962) so that when women entered it, they experienced relatively 11ttle status inconsistency; they were not restricted to nor needed to specialize in any one area within the field in order to reduce the impact of possible status inconsistency. Their spread over the specialties in social work reflects this notion. 


\section{CHAPTER VIII}

\section{CONCLUSIONS}

\section{Summary and Conclusions}

Everett Hughes developed the notion that when an individual holds an unexpected auxiliary characteristic of an incumbent of his status, he is caught in a dilemna because others do not know how to respond to him. They tend to react unfavorably, which in turn affects the individual's self-image. The individual sceks to maintain his selí-image and consequently adopts behavior which will reduce the impact of his discrepant status characteristic and bring favorable or at least consistent reactions from others. To use status consistency terminology, the Individual. is in an inconsistent status because of ranking high on one status dimension and low on another. He seeks to maintain his selfImage by adopting behavior which reduces the impact of his inconsistent status. To adopt this behavior is rewarding and not to adopt it is costly.

To categorize indiviauals as status inconsistents, some considerations must be made. The individual's discrepant characteristics must be perceived simultaneously by others. The individual must be aware of his inconsistent status. Moreover, the aiscrepart characteristic must be salient to the status to which the individual aspires. The incongruent stimuli must be fairiy divergent in order for the individual to feel the impact of his inconsistent status. And finally, the discrepant character- 
istic must be inconsistent with the normative expectations of the environment in which one moves.

For the woman as a professional, it was found that she falls into the category of status inconsistent since she holds the unexpected characteristic of being a fenale while a professional and meets all the above conditions of status inconsistency. Since she can do nothing about changing her discrepant characteristic of belng female, it is hypothesized that she adopts other behavior in order to bring her status characteristics in accord and reduce the impact of her inconsistent status set. This behavior may consist of avoidance, isolation and social segregation on the part of the female professional and her clients or colleagues who seek to avoid situations which may bring a reaction to her inconsistent status. The patterns of behavior taken are the basis of the eight hypotheses developed and tested in the study; 1) women enter the professions in smaller proportions than men, 2) women professionals do not participate fully in the colleague-group, 3) women professionals enter positions 1solated from the public, 4) women tend to be salaried, 5) women tend to be in separate career lines from positions of power and prestige, 6) women tend to fill the lower echelons of the profession, 7) women specialize in areas relating to the normatively accepted women's role and 8) women tend to deal with clients and patients of equal or lower status.

The data on which the hypotheses were tested were obtained from many different publications (as outlined in Chapter V). The data dealt with the sevei professions which were choser from among the thirteen professions established in Chapter III. These professions range from the traditional professions of zedicine and university teaching to borderline (In process) professions of veterinary medicine and soclal work. 
To summarize the results, it was found that the data generally support all the hypotheses with the exception of Hypothesis number three, which could not be tested. There seems to be a consistent pattern for the few women who do enter the professions to enter a ljmited number of them and to specialize in those areas which are related to the prescribed role of women in American society. Moreover, they tend to teach or enter research, work in educational institutions and be on salary. Women are not usually found in the top positions nor the most lucrative positions. Further, their career lines do not lead to the top positions and/ox they tend to fill the lower echelons within each profession.

It may be concluded that women professionals adopt this pattern throughout the professions, that their careex pattern is very different frcm that of male professionals, and it is suggested that they adopt this pattern in order to reduce the impact of their inconsistent status set.

\section{Recommendations for Future Research}

There is a serious lack of accurate detailed data concerning the sex distribution of professionals. The professional house organs do not keep statistics by sex, nor on all different areas within the profession; Census categories are too gross; sample surveys seem to be too narrow. There is a great need for better statistics in order to get an accurate picture of the entire profession and the place of men and women within it. I do not know the best way of gathering these statistics, but I would begin by urging those responsible for data collection in each profession and In the National Register to pay attention to the sex of its members In each tabulation. Next, sjince most professlons have a woman's assoclation, they could be urged themselves to make more accurate detailed 
studies for publication. They could also put pressure on the professional association's research bureau to gather statistics by sex.

The hypothesis concerning isolation of women from the public should be tested. Data would have to be collected by the investigator. But this notion that women are in positions isolated from the public is frequently mentioned in the literature and should be tested.

Other hypotheses in this study could have been extended and then tested. Hypothesis number eight concerning clients of equal or 10wer status might have been tested on other categories of people, not just women and children. These people may be categorized as "despised people" such as alcoholics and the mentally 111.

A study might be focused on those occupations which are in transition from being a non-profession to a profession. What precise changes" take place as an occupation is being up-graded? For social work, how important is the fact that men are increasing rapidly in proportion to women? Is this true also for other traditionally women's occupations?

Our study did not pay attention to changes over time. It is necessary to look at the professions over time in order to get the broad picture of what role women have played in the professions. If the percentage of women in the professions is decreasing, as has been suggested, or remaining the same, a historical look at the professions would help explain this trend and help predict which direction it will take in the future.

Finally, it has been suggested that if women are not increasing in the professions and if men are taking over top positions of formerly women's occupations, the future of women in the occupatinnal structure looks bleak. That is, women will be even lower on the occupational 
ladder than they are now. Other factors point to this. Taylor (1968: 488-9) suggests that the origins of those in the professions are stabilfzing, i.e., the professions tend to reproduce themselves. This suggests that the structure of the professions will more likely remain the same rather than change radically. Also, the income gap between men and women is and has been widenirg. Th1s suggests that economically women. are losing ground. Unemployment for women is also Increasing faster than for men and the gap is widening. From these trends, it appears that the occupational picture for women is getting worse. But it is a question which should be thoroughly studied and analyzed to see if this is in fact the case.

\section{Speculations}

On the basis of conducting this study, it is possible to speculate on the implications of the findings as they relate to women's position in American society. Table XLVI presents some background statistics. From this table, it is seen that $42 \%$ of the women are in the labor force as compared to $81.0 \%$ of the men. Concerning educational attainment, men and women are nearly equal except iri the highest levels where the percentage of men who have 5 or more years of college is greater than that of women. Since the bachelors degree is the first prerequisite for entering the professions, it is shown that women receive bachelors degress (constdering four years of college generally equivalent to a bachelors degree) in about the same percentage as men. So there is a considerable supply of women with four years of college from which candidates for the professions could be drawn. Women do not go on for further education in the same proportions as men, however. So the problem arises 
TABLE XLVI

PER CENT DISTRIBUTION OF POPULATION 18 YEARS OF AGE AND OLDER IN THE LABOR FORCE BY EDUCATION

AND BY SEX, 1968

\begin{tabular}{|c|c|c|c|c|}
\hline \multirow{2}{*}{ Education Level } & \multicolumn{2}{|c|}{ Population } & \multicolumn{2}{|c|}{ Labor Force } \\
\hline & Women & Men & Women & Men \\
\hline Number & $66,288,000$ & $57,989,000$ & $27,846,000$ & $47,255,000$ \\
\hline Per Cent & 100.0 & 100.0 & 100.0 & 100.0 \\
\hline Less than College & 81.1 & 75.4 & 77.2 & 74.4 \\
\hline College: & & & & \\
\hline $\begin{array}{l}1 \text { to } 3 \text { years } \\
4 \text { years } \\
5 \text { or more years }\end{array}$ & $\begin{array}{r}11.3 \\
5.7 \\
1.9 \\
\end{array}$ & $\begin{array}{r}12.4 \\
6.9 \\
5.3 \\
\end{array}$ & $\begin{array}{r}12.3 \\
7.4 \\
3.1 \\
\end{array}$ & $\begin{array}{r}12.2 \\
7.7 \\
5.9 \\
\end{array}$ \\
\hline Median & 12.2 & 12.2 & 12.4 & 12.3 \\
\hline
\end{tabular}

Source: Women's Bureau, 1969 Handbook on Women Workers, p. 178.

at the top levels of education. If one takes the position that women should be encouraged to go on for more training and assume a professional career, what do the professions have to offer women?

On the basis of this study, the consistent pattern throughout the professions tends to show that women are not given full professional standing. They tend to be given (or take) a somewhat reduced status within the profession because they tend to fill peripheral needs of the profession, tend not to attain top positions, tend to be restricted in participation in colleague-groups. In other words, women tend not to be included in Hughes' "inner fraternity." We are not concerned here with all the reasons why this pattern tends to exist. For now, the pattern appears and the point is that in sur society the rewards of professional 
standing are not as great for women as for men. Encouraging women to enter a long training period and make other sacrifices in order to becone a professional seems futile. Considering the pay-off in the profession and the social stigma for the women, it seems that greater sacrifices are being asked of women than of men. There are too many other alternatives open to women which are more compatible with her prescribed role and which require less effort and emotional cost.

It is clear that the number of women in the labor force has Increased. Fducational trends show that more women are going on to college and that education is directly related to employment. That is, the more education, the more likely it is that people will work. With these trends, it appears that the chances of wonen getting professional degrees and entering the professions would be increased. This is not the case, however. Some writers say that the percentage of women earning professional degrees and doctorates has decreased in the last 50 years; others say it has remained the sane. At any rate, it does not seem to be increasing. If it is true that women are not entering the professions in increasing proportions, one of the reasons may be found In the results of this study, that women do not attain full professional standing and receive the rewards due a professional. 


\section{BIBLIOGRAPHY}

\section{Status Inconsistency}

Broom, Leonard.

1959 "Social differentiation and stratification." Pp. 429-441 in Robert K. Merton, Leonard Broom and Leo S. Cottrell, Jr. (eds.), Sociology Today. New York: Harper and Row.

Fenchel, Gerd H.; Moderer, Jack H.; and Hartley, Eugene L.

1951 "Subjective status and the equilibration hypothesis." Journal of Abnormal and Social Psychology 46 (October):476-479.

Goffman, Erving.

1957 "Status consistency and preference for change in power distribution." American Sociological Review 22 (June):275-81.

Homans, George C.

1961 Social Behavior: Its Elementary Forms. New York: Harcourt, Brace arid World.

Hughes, Everett Cherrington.

1945 "Dilemmas and contradictions of status." American Journal of Sociology 50:353-359.

Jackson, Elton.

1962 "Status inconsistency and symptoms of stress." American Sociologica1 Review 27 (August);469-480.

Lenski, Gerhard.

1956 "Social participation and status crystallization." American Soctologica: Review 21 (August):458-464.

Malewsiki, Andzej.

1963 "The degree of status incongruence and its effects." Pp. 303-308 in Reinherd Bendix and Seymour Martin Lipset (eds.), Class, Status and Power. diew York: The Free Press, 196C.

\section{Professiuns}

Barber, Bernard.

1965 "Some problens in the sociology of the professions." Pp. 1-14 in Kerneth S. Lynn an' the editors of Daedalus, The Professions in America. Boston: Beacon Press. 
Etzioni, Amitai (ed.).

1969 The Semi-Professions and Their Organization. New York: The Fiee Press.

Ginzberg, Eli.

1968 "Professional manpower for an affluent society: the opportunity gap." Pp. 4-10 in American Medical Women's Association, The Fuller Utilization of the Woman Physician. Washington, D. C.: Women's Bureau, U. S. Department of. Labor.

Goode, William J,

1969 "The theoretical limits of professionalization." Pp. 266-313 in Amital Etzioni, The Semi-Professions and Their Organization. New York: The Free Press.

Hodge, Robert W.; Paul M. Siegel; and Peter H. Ross1.

1966 "Occupational prestige in the United States: 1925-1963." Pp. 322334 in Reinhard Bend $1 x$ and Seymour Martin Lipset, Class, Status and Fower. New York: The Free Press.

Lynn, Kenneth S. and the Editors of Daedalus.

1965 The Professions in America. Boston: Beacon Press, 1965.

Moore, Wilbert.

1967 "Ecoronic and professional institutions." Pp. 276-328 in Neil J. Smelser (๕a.), Sociology. New York: John Wiley and Sons, Inc.

Stafford, Rita L.

1967 "An analysis of consciously recalled motivating factors and subsequent professional involvement for American women in New York state." Unpublished Ph.D. dissertation, School of Education, New York University. P. 151 in Carol Lopate, Women in Medicine. Baltimore: Johns Hopkins Press, 1968.

Taylor, Lee.

1968 Occupational Sociology. New York: Oxford University Press.

Toren, Nina.

1969 "Semi-professionalism and social work: a theoretical perspective." Pp. 141-194 in Amitai Etzioni, The Semi-Profiessions and Their Organization. New York: The Free Press.

Vollwer, Howard M. and Donald L. Mills (eds.).

1966 Professionalization. Englewood Cliffs, New Jersey: PrenticeHall, Ine.

Wilensky, Harold.

1964 "The professionalization of everyone?" American Journal of Sociology 70 (September) :137-1.58. 
Women

Bernard, Jessie.

1964 Academic Women. University Park, Pennsylvania: Pennsylvania State University Press.

Caplow, Theodore.

1954 The Sociology of Work. New York: McGraw-Hi11 Book Company.

Lewis, Edwin C.

1968 Developing Woman's Potentlal. Ames, Iowa: Iowa State University Press.

Lifton, Robert Jay (ed.).

1965 The Woman in America. Boston: Beacon Press.

Mattfeld, Jacquelyn A. and Carol G. Van Aken (eds.).

1965 Women and the Scientific Professions. Cambridge: The MII Press.

Parrish, John B.

1961 "Professional womanpower as a national resource." Quarterly

Review of Economics and Business 1 (Eebruary):54-63.

Rossi, Alice.

1965 "Women in science." Science 148 (May 28):1196-1202.

Data

American Anthropological Association.

1968 American Anthropologist 70 (August)

Ameriaan Association of Junicr Collegas

1970 Junior College Journal (January).

American Association of University Prcfessors.

1970 American Association of University Professors Bulletin (January).

American College of Surgeons.

19681968 Directory. Chicago: Lakeside Iress.

American Dental Association.

19681968 American Dental Directory.

American Economics Association.

1969 The American Economics Review LIX (May).

American Forestry Associat! un.

1969 Americar Forests 75 (January). 
iuciaty.

$\therefore$ American Mathenatical Suciety 75 (November).

$\therefore$ istion.

- iss (December 13).

at Directory, Pt. I

a's Association.

: il:zation of the Woman Physician. Washington,

.'s sureau, U. S. Department of Labor.

. Al Soclety.

he American Meteorological Society 51 (February).

is Association.

hologist 25 (February).

$\therefore$ Association.

. Llogical Review (February).

- Association.

:he Acerican Statistical Association 64 (June).

.. Len. Dniversity Park, Pennsylvania: Pennsylvania isity.

of America.

. Society of America Bulletin 80 (November).

John A. Centra.

... veterinarian." Personnel and Guidance Journal 46 .975 .

aca of American Medicine. New York: Macmillan Co.

$=S$. (director of the Commission on the Survey of

- of Dentistry. Washington, D. C.: American Council

*ns.

- coker, Ir.

$\because$ physician in public health conflict and reconciliation Taud professional roles." Sociology and Social Research 5.

Vailcine. Baltimore: Johns Hopkins Press.

. ine.

C Nedical Specialists. Vol. XIII. St. Louls: Von $\therefore a s s$, Inc. 
Maryland State Planning Commissicn.

1962 Medical Education and Research Needs in Maryland. Baltimore: State Planning Department.

National Education Association.

1955 Teacher Supply and Demand, 1954-55. Research Bulletin 33 (December).

1968 Salaries In Higher Edication, 1967-68. Research Report 1968-R7. Washington, D. C.: National Education Association.

National Education Association, National Council of Administrative Women in Education.

1965 Wanted - More Women in Education Leadership. Washington, D. C.: National Education Association.

National Social Welfare Assembly, U. S. Department of Labor and U. S. Department of Health, Education and Welfare.

1960 Salaries and Working Conditions of Social Welfare Manpower in 1960. New Yorl:: Nat1onal Social Welfare Assembly, Inc.

Parrish, John B.

1962 "Women in top level teaching and research." American Association of University Women Journal (January):99-107.

Rayack, E1ton.

1967 Professional Power and American Medicine: The Economics of the American Medical Association. Cleveland: The World Publishing Co.

Reed, Louis.

1968 Studies of the Incones of Physicians and Dentists. Washington, D. C.: U. S. Department of Health, Education and Welfare, Social Security Administration.

Sigma $X i$

1970 American Scientist 58 (March-Apri1).

Society for the Study of Evolution.

1969 Evolution - International Journal of Organic Evolution 23 (December).

U. S. Department of Conmerce, Bureau of the Census.

1963 United States Cerisus of Population: 1960. Occupational Characteristics, PC(2)-7A. Washington, D. C.: U. S. Government Printing office.

1964 United States Census of Population: 1960. Characteristics of Professional Workers, PC(2)-7E. Washington, D. C.: U. S. Government Printing Office. 
109

U. S. Department of Health, Education and Welfare. 1962 Health Manpower Sourcbook, Section 14, "Medical specialists." Washington, D. C.: U. S. Government Printing Office.

U. S. Department of Health, Education and Welfare, Office of Education. 1969 Higher Education Salaries, 1966-67. National Center for Educatonal Statistics. Washington, D. C.: U. S. Government Printing Office.

U. S. Department of Labor, Women's Bureau.

19621962 Handbook on Women Workers. Washington, D. C.: U. S. Government Printing Office.

19691969 Handbook on Women Workers. Washington, D. C.: U. S. Government Printing office.

U. S. National Science Foundation.

1969 American Science Manpower 1966. NSF 68-7. Washington, D. C.: U. S. Government Printing Office. 